\title{
Quantifying the Mineralization of C-13-Labeled Cations and Anions Reveals Differences in Microbial Biodegradation of Herbicidal lonic Liquids between Water and Soil
}

Wilms, Wiktoria; Wozniak-Karczewska, Marta; Niemczak, Michal; Lisiecki, Piotr; Zgola-Grzeskowiak, Agnieszka; Lawniczak, Lukasz; Framski, Grzegorz; Pernak, Juliusz; Owsianiak, Mîkolaj; Vogt, Carsten Total number of authors:

13

Published in:

ACS Sustainable Chemistry and Engineering

Link to article, DOI:

10.1021/acssuschemeng.9b07598

Publication date:

2020

Document Version

Peer reviewed version

Link back to DTU Orbit

Citation (APA):

Wilms, W., Wozniak-Karczewska, M., Niemczak, M., Lisiecki, P., Zgola-Grzeskowiak, A., Lawniczak, L., Framski, G., Pernak, J., Owsianiak, M., Vogt, C., Fischer, A., Rogers, R. D., \& Chrzanowski, L. (2020). Quantifying the Mineralization of C-13-Labeled Cations and Anions Reveals Differences in Microbial Biodegradation of Herbicidal lonic Liquids between Water and Soil. ACS Sustainable Chemistry and Engineering, 8(8), 3412-3426. https://doi.org/10.1021/acssuschemeng.9b07598

\section{General rights}

Copyright and moral rights for the publications made accessible in the public portal are retained by the authors and/or other copyright owners and it is a condition of accessing publications that users recognise and abide by the legal requirements associated with these rights.

- Users may download and print one copy of any publication from the public portal for the purpose of private study or research.

- You may not further distribute the material or use it for any profit-making activity or commercial gain

- You may freely distribute the URL identifying the publication in the public portal 
Wilms, W.; Wozniak-Karczewska, M.; Niemczak, M.; Lisiecki, P.; Zgola-Grzeskowiak, A.; Lawniczak, L.; Framski, G.; Pernak, J.; Owsianiak, M.; Vogt, C.; et al. Quantifying the Mineralization of C-13-Labeled Cations and Anions Reveals Differences in Microbial Biodegradation of Herbicidal Ionic Liquids between Water and Soil. ACS Sustain. Chem. Eng. 2020, 8 (8), 3412-3426. https://doi.org/10.1021/acssuschemeng.9b07598. 


\section{Quantifying the mineralization of ${ }^{13} \mathrm{C}$-labeled cations and anions reveals differences in microbial biodegradation of herbicidal ionic liquids between water and soil}

Wiktoria Wilms, ${ }^{a}$ Marta Woźniak-Karczewska, ${ }^{a}$ Michal Niemczak,,${ }^{\text {a,g }}$ Piotr Lisiecki, ${ }^{a}$ Agnieszka Zgoła-Grześkowiak, ${ }^{\mathrm{a}}$ Łukasz Lawniczak, $^{\mathrm{a}}$ Grzegorz Framski, ${ }^{\mathrm{b}}$ Juliusz Pernak, ${ }^{\mathrm{a}}$ Mikołaj Owsianiak, ${ }^{\mathrm{c}}$ Carsten Vogt, ${ }^{\mathrm{d}}$ Anko Fischer, ${ }^{\mathrm{e}}$ Robin D. Rogers, ${ }^{\text {f,g }}$ Łukasz Chrzanowski ${ }^{\mathrm{a}, \mathrm{g}^{*}}$

${ }^{a}$ Department of Chemical Technology, Poznan University of Technology, Poznan 60-965, Poland

${ }^{b}$ Institute of Bioorganic Chemistry, Polish Academy of Sciences, Noskowskiego 12/14, 61-704 Poznan, Poland

${ }^{\mathrm{c}}$ Division for Sustainability, Department of Technology, Management and Economics, Technical University of Denmark, Produktionstorvet, Bygn. 424, 2800 Kgs. Lyngby, Denmark

${ }^{\mathrm{d}}$ Helmholtz Centre for Environmental Research, UFZ Department of Isotope Biogeochemistry, Permoserstrasse 15, 04318 Leipzig, Germany

${ }^{\mathrm{e}}$ Isodetect GmbH, Deutscher P1. 5B, 04103 Leipzig, Germany

f 525 Solutions, Inc., PO Box 2206, Tuscaloosa, AL 35403, USA

${ }^{\mathrm{g}}$ College of Arts \& Sciences, The University of Alabama, Tuscaloosa, AL 35487, USA

*Corresponding authors e-mail: 1ukasz.chrzanowski@put.poznan.p1 


\begin{abstract}
Characterization of the biodegradability of herbicidal ionic liquids (HILs) using the industry standard activated sludge methodology is thought to be insufficient to fully understand the biodegradation of HILs in the environment because cations and anions of the HILs may have different potential for biodegradation in aquatic and terrestrial systems. To test this hypothesis, we conducted laboratory microcosm experiments using ${ }^{13} \mathrm{C}$-labelled cations and anions forming benzyldodecyldimethylammonium 4-chloro-2-methylphenoxyacetate ([C $12-\mathrm{BA}][\mathrm{MCPA}])$ and evaluated their biodegradation potential in a soil with known history of herbicide exposure, and in water (mineral medium) augmented with microorganisms present in activated sludge. The biodegradability of the cation and anion was found to depend on the test system (water or soil). The cation was mineralized in the water, whereas the anion was fully utilized in the soil. These results suggest that performing biodegradation tests using differently ${ }^{13} \mathrm{C}$-labelled species of the target HIL and mimicking various environmental compartments (e.g., soil, activated sludge) is needed to provide a better understanding of the fate of HILs in the environment. They also indicate that biodegradation kinetic parameters of HILs derived from experiments performed in aqueous systems should not be used to estimate biodegradation rates in terrestrial environments.
\end{abstract}

Keywords: herbicides, ionic liquids, biotransformation, mineralization, biodegradation, activated sludge, soil microcosms, MCPA

Short description: The ions in herbicidal ionic liquids mineralize independently and differently in water vs. soil. 


\section{Introduction}

Due to many unique properties, Ionic Liquids (ILs, defined as organic salts consisting of cation and anion that are liquid below $100^{\circ} \mathrm{C}^{1}$ ) have gained more and more commercial importance, thus they are becoming increasingly attractive for industrial use. ${ }^{2,3}$ As a result, the risk of their unintended introduction to the environment is quickly rising, and given the usually low or nonvolatility of ILs, the routes to environmental contamination will likely be water or soil. While this alone argues for a careful examination of the degradation of ILs in the environment, there is another class of ILs which have purposely been designed to be applied in agricultural soil compartments, Herbicidal Ionic Liquids (HILs). ${ }^{4}$

The lack of innovation in terms of new herbicides since the 1980s, along with recently discussed disadvantages of commercially used compounds, has forced the search for new solutions. ${ }^{5}$ Herbicides in general are susceptible to volatilization, leaching and runoff, as well as accumulation in surface waters and soils, making them persistent in the environment. ${ }^{6}$ Moreover, due to the extensive use of various herbicides, plants exhibit growing resistance towards these formulations. ${ }^{7}$ Additionally, commercially used herbicidal products often involve compounds (e.g. ethoxylated etheralkylamine, solvent naphtha) responsible for enhancing the penetration of the active ingredient into the plant. However, these are often characterized by even higher toxicity and increase the overall negative impact on our environment. ${ }^{8}$

By taking inspiration from the tunability of physical, chemical, and biological properties for HILs, ${ }^{9}$ and the fact that most classic herbicides are either acids or bases, Pernak et al. ${ }^{4,10}$ proposed to revitalize the field of crop protection by combination of herbicidal anions with cations having good wetting properties, to prepare HILs with a range of advantageous features. For example, HILs can be designed to enhance herbicidal activity while reducing risk of drift and contamination. ${ }^{11}$ Proper selection of ions results in salts with reduced volatility and enhanced ability to penetrate plants. Moreover, their decreased accumulation in soil is due to adjustable water solubility which can prevent wash off and runoff. ${ }^{12}$ Indeed, HILs have been shown to possess increased efficacy in comparison to currently used commercial formulations containing the same herbicide. ${ }^{4,10,11,13}$ HILs may also be an attractive solution to overcome plant resistance strategies, since via their unique 
ionic structure they might not activate the same resistance mechanisms in weeds and therefore be more effective in smaller doses. ${ }^{14}$

As a result of the rising interest in HILs, the issue of their toxicity has also recently been intensively considered, i.e. acute toxicity of HILs was evaluated on rats, ${ }^{4}$ fish, ${ }^{15}$ and algae. ${ }^{4,15,16}$ For their toxicity toward microorganisms, the most commonly used parameters are minimum inhibitory concentration (MIC), ${ }^{17,18}$ or more advanced methods, through adaptive changes at the level of cell membranes of microorganisms. ${ }^{19}$ So far, it has been shown that HILs derived from two of the most popular systemic, selective herbicides from the group of phenoxy acids (2,4-dichlorophenoxyacetic acid and 4-chloro-2-methylphenoxyacetic acid) were less toxic towards soil microorganisms, rainbow trout and rats than the commercialized synthetic herbicides containing these very herbicides. ${ }^{10,15,19}$ These reports together with knowledge of HILs' physicochemical properties are becoming useful for assessing the potential risk of environmental pollution, and thus may find application as guidelines for setting legislation for their future use. ${ }^{20}$

It is not just toxicity, however, which needs to be more fully assessed, but also biodegradability. The term 'biodegradation' refers to biotransformation of a given compound into a product characterized by different, preferably less complex, chemical structure. ${ }^{21}$ This definition includes primary biodegradation, which corresponds to the dissipation of the initial compound, and ultimate biodegradation, which leads to complete mineralization of a given compound, resulting in the formation of $\mathrm{CO}_{2}, \mathrm{H}_{2} \mathrm{O}$, energy, and biomass. ${ }^{21}$

Since HILs will be applied directly to plants and typically exhibit low vapor pressures, they will enter the environment through the soil and water. The current standards regarding new chemicals introduced to the environment, including HILs, require that the chemical can be mineralized to avoid the accumulation and distribution of persistent and possibly toxic metabolites in soil and groundwater. ${ }^{22}$ This approach is fully consistent with the principles of green chemistry, as well as the concept of sustainable development. ${ }^{23}$

The Organization for Economic Co-operation and Development (OECD) recommends assessment of biodegradation of chemical compounds according to tests that reflect the conditions prevailing in the environmental niche in which the analyzed compound may appear. In the case of ILs, most researchers do not follow these patterns, instead simply relying on the current biodegradability tests for aqueous environments, which include the six test variants No. 301 A-F: DOC Die-Away Test (301 A), CO 2 Evolution Test (301 B), Modified MITI Test (I) (301 C), Closed 
Bottle Test (301 D), Modified OECD Screening Test (301 E) and Manometric Respirometry Test $(301 \mathrm{~F}){ }^{24}$ In the most popular test $301 \mathrm{~F}$, the target compound is added as the sole carbon source for microorganisms from activated sludge in a mineral medium in closed bottles. Mineralization is monitored by uptake of oxygen and production of $\mathrm{CO}_{2}$ which is followed for 28 days. The extent of mineralization is then calculated relying on both $\mathrm{O}_{2}$ consumption and $\mathrm{CO}_{2}$ production. This type of data can demonstrate the overall potential of a given HIL for mineralization in an aqueous environment, however, these tests do not allow the monitoring of the degree of decomposition of the cation and anion individually, ${ }^{25}$ as well as direct evidence of mineralization and assimilation of the target compound.

In order to simulate the biodegradation of organic chemicals under environmentally realistic conditions in soil, sediment, or surface water the following tests should be used: Aerobic and Anaerobic Transformation in Soil (307); Aerobic and Anaerobic Transformation in Aquatic Sediment Systems (308); and Aerobic Mineralization in Surface Water - Simulation Biodegradation Test (309). Bearing in mind the agrochemical use of HILs, the first choice for biodegradation research should be soil. Recently, a few initial reports focusing on both biotransformation, as well as mineralization of ILs in soil have appeared, however they did not follow precisely OECD 307 requirements. $^{22,26}$ The experiments according to OECD 307 should provide the rate of degradation of the analyzed substance, i.e. IL or HIL, together with rates of formation and subsequent decline of metabolites, to which plants and soil organisms may be exposed.

Up to now, even knowledge regarding mineralization of each individual ion comprising a given ILs is still insufficient. Bearing in mind the tunability of ILs and the rapid publication of numerous new compounds with very different physicochemical properties, as well as possible interactions between the ions, potential synergistic or antagonistic effects also need to be considered for biodegradation assessment. The result of the fact that an IL is comprised of at least one cation and at least one anion, means that the susceptibility to a microbial attack can be substantially different for the cation and the anion, which consequently can be mineralized to different and variable degrees.

A more complete understanding of the behavior of ILs in soil during biodegradation is, in our opinion, possible only if both tests (e.g. 301 and 307) are used simultaneously, such that the differences in the biodegradation of the cation and the anion can be evaluated. Moreover, those 
tests should be appropriately adjusted to allow for the reliable comparison of the obtained data (e.g., time duration of experiment or determination of metabolites). Herein, we report our initial efforts to explore and demonstrate the concept of environmentally-relevant biodegradation assessment focusing on the IL-soil interactions, using the HIL, benzyldodecyldimethylammonium (4-chloro-2-methylphenoxyacetate) $\left(\left[\mathrm{C}_{12}-\mathrm{BA}\right][\mathrm{MCPA}]\right)$, which is comprised of a cation with surface-active, as well as antimicrobial properties, and an anion which is a classic herbicide.

Stable isotope tools are increasingly applied for in-depth evaluation of biodegradation of organic pollutants ${ }^{27}$. In this study, either the cation or the anion was labeled with ${ }^{13} \mathrm{C}$ and, using enhanced 301 and 307 test methodologies, the mineralization of cation and anion was separately evaluated by monitoring the incorporation of the ${ }^{13} \mathrm{C}$-label into $\mathrm{CO}_{2}$. This ${ }^{13} \mathrm{C}$-labeling approach had already been applied for assessing the biodegradation potential of pollutants that resist microbial degradation such as benzene, PAHs, monochlorobenzene or pesticides. ${ }^{28-32}$ The assimilation of cation and anion of $\left(\left[\mathrm{C}_{12}-\mathrm{BA}\right][\mathrm{MCPA}]\right)$ was investigated by monitoring the incorporation of the ${ }^{13} \mathrm{C}$-label into microbial fatty acids. Metabolites were analyzed, in order to decipher biodegradation pathways of $\left(\left[\mathrm{C}_{12}-\mathrm{BA}\right][\mathrm{MCPA}]\right)$.

\section{Results and Discussion}

For this study we chose the herbicide 4-chloro-2-methylphenoxyacetic acid [HMCPA] (Table 1), which along with glyphosate, dicamba, and 2,4-dichlorophenoxyacetic acid [H2,4-D], is among the 10 most common conventional pesticide active ingredients used in the home and garden. ${ }^{33}$ Pernak and others have demonstrated the possibility of transforming these common herbicides into HILs by combining herbicidal anions with functionalized organic cations. ${ }^{4}$ For example, HILs containing the $[\mathrm{MCPA}]^{-}$anion have been shown to possess increased efficacy in comparison to currently used commercial formulations containing the same herbicidal compound due to low values of contact angle and surface tension that enhanced the wetting of plants, spray retention, absorption, cuticle penetration and translocation of the active ingredient. ${ }^{4,13,34}$ Furthermore, MCPA-based HILs' droplets were found to possess a greater contact area, which facilitates the penetration

of the active substance into the interior of the plant and also prevents the droplets from falling off the leaf. 13,35 
Table 1. Characteristics of $[\mathrm{BA}][\mathrm{X}]$, [HMCPA], and [BA][MCPA].

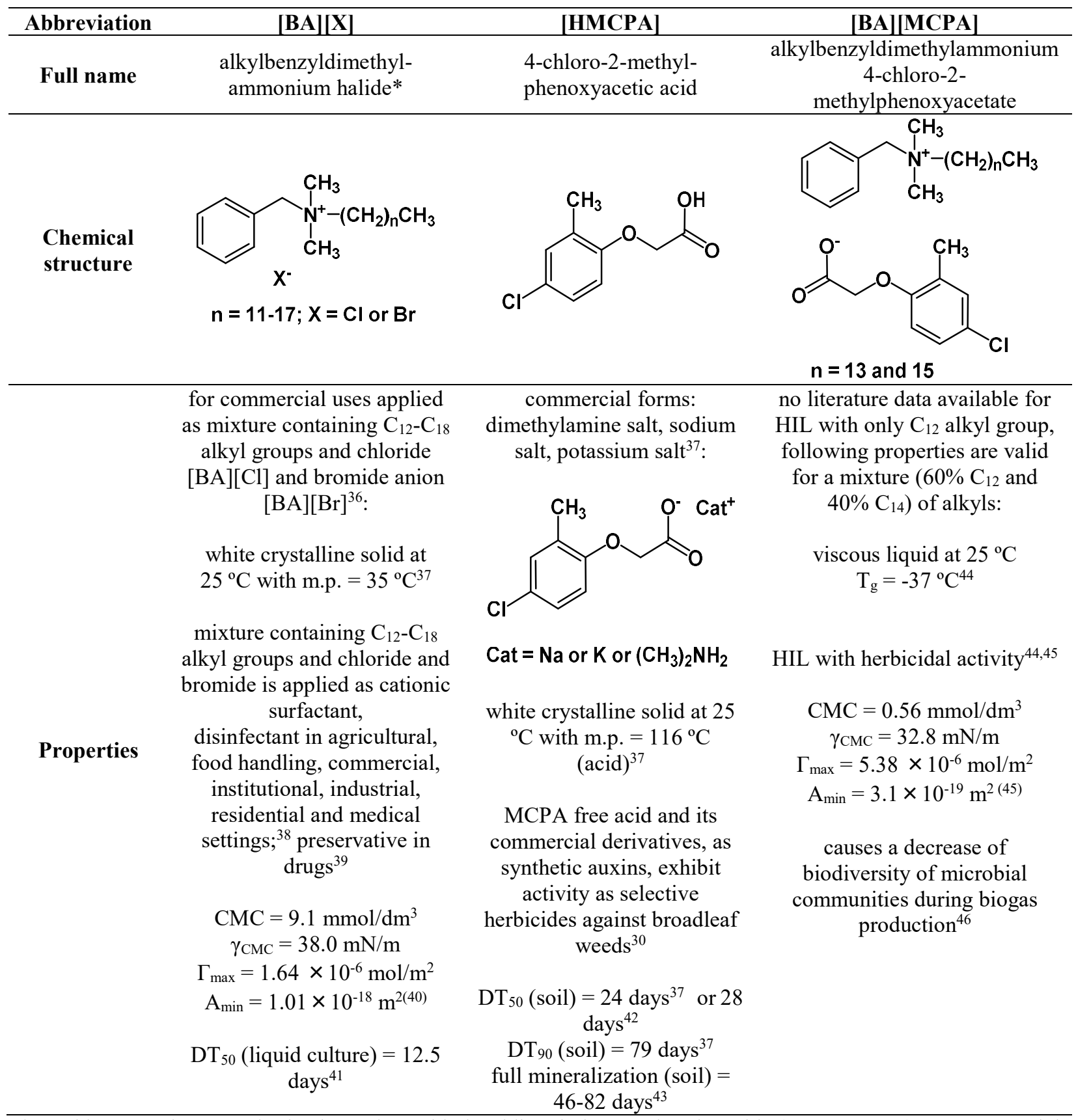

*For this research we synthesized pure benzyldodecyldimethylammonium bromide ([C $\left.\left.\mathrm{C}_{12}-\mathrm{BA}\right][\mathrm{Br}]\right)$, no commercial mixture was used.

As a systemic herbicide, [HMPCA] is directly applied onto soil or sprayed over crops, and from there, may enter into soil and water compartments. Moreover, due to high solubility in water and low adsorption of its currently applied commercial forms, this herbicide has often been detected in 
surface and groundwater, which may lead to significant environmental problems as well as health risk. $^{42}$ This herbicide is biodegraded to phenol derivatives, mainly 2-methylphenol [2-MP], 4chlorophenol [4-CP], and 4-chloro-2-methylphenol [4-C-2-MP], and these are later mineralized. ${ }^{47}$

For the model cation, we looked for a cation which exhibits high surface-active properties,

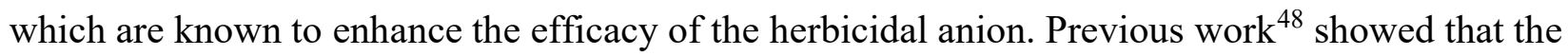
benzalkonium cation (containing $60 \% \mathrm{C}_{12}$ and $40 \% \mathrm{C}_{14}$ alkyl substituents) $[\mathrm{BA}]^{+}$paired with the $[2,4-\mathrm{D}]^{-}$anion provided excellent control of weeds such as common lambsquarters (Chenopodium album), field pennycress (Thlaspi arvense), and shepherd's-purse (Capsella bursa pastoris). Interestingly, standard herbicide formulations containing 2,4-D as the sodium salt demonstrated much slower phytotoxic effects and eventually was less effective presumably due to lack of surface activity. $^{48}$

In addition, the $[\mathrm{BA}]^{+}$halides are representatives of quaternary ammonium compounds (QACs) which are cationic surfactants exhibiting activity towards microorganisms. ${ }^{49}$ Due to their extensive use in various domestic, agricultural, healthcare, and industrial applications like disinfectants, surfactants, drugs and personal care products, $[\mathrm{BA}]^{+}$is expected to enter mainly the aquatic environment through wastewater effluent. ${ }^{41}$ For instance, $[\mathrm{BA}][\mathrm{Cl}]$ consisting of $\mathrm{C}_{12}$ and $\mathrm{C}_{14}$ alkyls was found in high concentration of $9 \mathrm{mg} / \mathrm{kg}$ of dry weight in sewage sludge. ${ }^{36}$

The biotransformation pathway of $[\mathrm{BA}]^{+}$involves dealkylation that leads to formation of benzyldimethylamine [BDMA] and dodecanol (further oxidized to decanoic acid), whereas [BDMA] is subsequently transformed to dimethylamine [DMA] and benzoic acid. Finally, both [DMA] and benzoic acid are mineralized, resulting in the production of ammonia and $\mathrm{CO}_{2} .{ }^{41,50}$

With clearly different biodegradation pathways, we chose to study the [ $\left.\mathrm{C}_{12}-\mathrm{BA}\right][\mathrm{MCPA}]$. This HIL with exclusively benzyldodecyldimethylammonium as the cation (i.e., not the commercial $\mathrm{C}_{12}-\mathrm{C}_{14}$ mixture) has not been described before. However, the HIL consisting of the $[\mathrm{BA}]^{+}$cation (containing $60 \% \mathrm{C}_{12}$ and $40 \% \mathrm{C}_{14}$ alkyl substituents) paired with the [MCPA] $]^{-}$anion was the subject of an international patent application in $2008^{44}$ and two reports. ${ }^{45,46}$ It is a viscous, orange liquid at room temperature with a glass transition temperature $\left(\mathrm{T}_{\mathrm{g}}\right)$ of $-37^{\circ} \mathrm{C}$. Its herbicidal activity against common dicotyledonous weed - white mustard (Sinapis alba L.), tested in greenhouse experiments, was found to be approx. 10-30\% higher compared to the commercial preparation containing a mixture of sodium and potassium salts of MCPA (Chwastox Extra 300 SL). ${ }^{44}$ 
Subsequent studies revealed that the enhancement in efficacy was related to the surface activity of $[\mathrm{BA}][\mathrm{MCPA}]$, where the surface-activity parameters (critical micelle concentration (CMC), surface tension at CMC $\left(\gamma_{\mathrm{CMC}}\right)$, surface excess $\left(\Gamma_{\max }\right)$, and minimum surface occupied by a molecule $\left.\left(A_{\min }\right)\right)$ were at the level of cationic surfactant activity. ${ }^{45}$ Recently, it was found that the presence of $[\mathrm{BA}][\mathrm{MCPA}]$ in a concentration range from 20 to $125 \mathrm{mg} / \mathrm{L}$ initiated significant decrease in biodiversity of microbial communities and in biogas production. ${ }^{46}$

\section{Synthesis and characterization}

To follow the fate of either the cation or anion, we chose to synthesize one defined HIL in three variants. The first one possessed a ${ }^{13} \mathrm{C}$-labeled phenyl ring in the cation and an unlabeled anion; the second contained an unlabeled cation and a ${ }^{13} \mathrm{C}$-labeled phenyl ring in the anion; while the third consisted of both unlabeled ions. Additionally, due to the fact that the commercial $[\mathrm{BA}]^{+}$cation contains various alkyl substituents, we decided to synthesize pure benzyldodecyldimethylammonium bromide. ${ }^{13} \mathrm{C}$-labeled $\left(\left[\mathrm{C}_{12}-\mathrm{BA} *\right][\mathrm{Br}]\right)$ or unlabeled $\left(\left[\mathrm{C}_{12}-\mathrm{BA}\right][\mathrm{Br}]\right)$. These were obtained via a quaternization reaction between dodecyldimethylamine and ${ }^{13} \mathrm{C}$-labeled or unlabeled benzyl bromide conducted in boiling acetonitrile (ACN). After evaporation of ACN the product was isolated from the post-reaction mixture by two phase (water:hexane) extraction techniques (Fig. S1, Electronic Supplementary Information - ESI). Subsequently, to make the HILs, the $\left[\mathrm{C}_{12}-\mathrm{BA}\right][\mathrm{Br}]$ or $\left[\mathrm{C}_{12}-\mathrm{BA} *\right][\mathrm{Br}]$ was subjected to ion-exchange in a metathesis reaction with the potassium salt of ${ }^{13} \mathrm{C}$-labeled or unlabeled 4-chloro-2methylphenoxyacetic acid ([K][MCPA*] or $[\mathrm{K}][\mathrm{MCPA}])$ according to a method described earlier (Fig. S2, ESI). ${ }^{44}$ All of the products (Fig. 1) were obtained in high yields (>95\%) and with high purities as determined by NMR (Fig. S3-S10, ESI), as well as elemental analyses. All products were liquids at $25^{\circ} \mathrm{C}$. Details of the synthesis of the compounds and their full characterization are provided in the Experimental Section. 


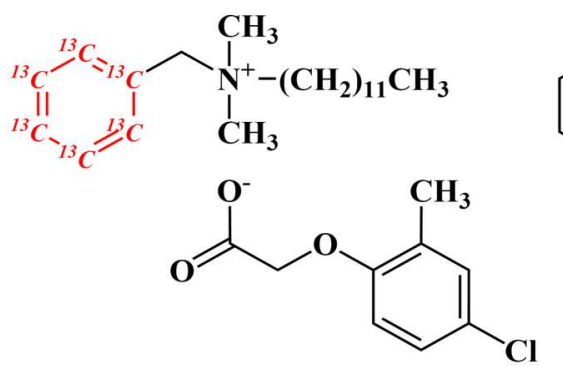

[BA*][MCPA]<smiles>CCCCCC</smiles><smiles>Cc1cc(Cl)ccc1OCC(=O)[O-]</smiles>

[BA] $\left[\mathrm{MCPA}^{*}\right]$<smiles>CCCCCCC</smiles><smiles>Cc1cc(Cl)ccc1OCC(=O)[O-]</smiles>

[BA] [MCPA]

Fig. 1. Structures of ${ }^{13} \mathrm{C}$-labeled $\left[\mathrm{C}_{12}-\mathrm{BA} *\right][\mathrm{MCPA}],\left[\mathrm{C}_{12}-\mathrm{BA}\right]\left[\mathrm{MCPA}^{*}\right]$, and unlabeled $\left[\mathrm{C}_{12-}\right.$ $\mathrm{BA}][\mathrm{MCPA}]$.

\section{Mineralization in liquid microcosms using modified OECD $301 \mathrm{~F}$ test}

In order to fully explore the mineralization, we modified the OECD 301F test as follows: mineralization of ${ }^{13} \mathrm{C}$-labeled HILs was analyzed by determining the carbon isotope ratio $\left({ }^{13} \mathrm{C} /{ }^{12} \mathrm{C}\right)$ of $\mathrm{CO}_{2}$ (given as delta-notation: $\delta^{13} \mathrm{CO}_{2}$, see Eq. 1 in the Experimental Section) generated by microorganisms in metabolic processes by employing Gas chromatography - combustion - isotope ratio mass spectrometry (GC-C-IRMS). This method allowed for monitoring the oxidation of ${ }^{13} \mathrm{C}$ labeled $\left[\mathrm{C}_{12}-\mathrm{BA}^{*}\right]^{+}$cation and the $\left[\mathrm{MCPA}^{*}\right]^{-}$anion, respectively, to $\mathrm{CO}_{2}$ (mineralization). Since degradation of MCPA is well known in literature, only [ $\left.\mathrm{C}_{12}-\mathrm{BA} *\right][\mathrm{Br}]$ and $\left[\mathrm{C}_{12}-\mathrm{BA}\right][\mathrm{Br}]$ were used as reference. In this test, the evolution of ${ }^{13} \mathrm{C}$-labeled $\mathrm{CO}_{2}$ proved the full degradation of the labeled aromatic ring, while the lack of increasing $\delta^{13} \mathrm{CO}_{2}$-values would indicate that the ${ }^{13} \mathrm{C}$-labeled aromatic ring was not mineralized or underwent only limited biotransformation (primary biodegradation as indicated by monitoring its concentration). Liquid microcosms were prepared using activated sludge collected at a municipal waste water treatment plant (for details see Experimental Section). The $\delta^{13} \mathrm{CO}_{2}$-values of the mineralization test for liquid microcosms (Table

2) revealed that the ${ }^{13} \mathrm{CO}_{2}$ originated exclusively from ${ }^{13} \mathrm{C}$-labeled $\left[\mathrm{C}_{12}-\mathrm{BA}{ }^{*}\right]^{+}$cations (in $\left[\mathrm{C}_{12}-\right.$ $\left.\mathrm{BA}^{*}\right][\mathrm{MCPA}]$ and $\left[\mathrm{C}_{12}-\mathrm{BA}^{*}\right][\mathrm{Br}]$, while ${ }^{13} \mathrm{C}$-labeled [MCPA*]' anion was not mineralized.

Table 2. $\delta^{13} \mathrm{CO}_{2}$-values [\%o] emitted in liquid microcosm samples containing both ${ }^{13} \mathrm{C}$-labeled and unlabeled $\left[\mathrm{C}_{12}-\mathrm{BA}\right][\mathrm{MCPA}]$. 


\begin{tabular}{l|ccccccc}
\hline Damp. & $\mathbf{0}$ & $\mathbf{5}$ & $\mathbf{1 0}$ & $\mathbf{2 0}$ & $\mathbf{3 0}$ & $\mathbf{4 0}$ & $\mathbf{7 3}$ \\
\hline$\left[\mathbf{C}_{12}-\mathbf{B A}^{*}\right][\mathbf{M C P A}]$ & -7.2 & $9022.2^{\mathrm{a}}$ & 9265.3 & $>10000$ & $>10000$ & $>10000$ & $>10000$ \\
{$\left[\mathbf{C}_{\mathbf{1 2}}-\mathbf{B A}\right][\mathbf{M C P A}]$} & -17.2 & -14.5 & -22.7 & -17.3 & -18.1 & -17.2 & -10.8 \\
{$\left[\mathbf{C}_{12}-\mathbf{B A}\right][\mathbf{M C P A}]$} & -19.5 & -27.4 & -30.7 & -28.6 & -30.7 & -30.0 & -27.6 \\
{$\left[\mathbf{C}_{12}-\mathbf{B A} \mathbf{A}^{*}\right][\mathbf{B r}]$} & -18.8 & 6545.2 & $>10000$ & $>10000$ & $>10000$ & $>10000$ & $>10000$ \\
{$\left[\mathbf{C}_{12}-\mathbf{B A}\right][\mathbf{B r}]$} & -19.6 & -24.1 & -31.6 & -30.1 & -28.8 & -28.3 & -26.3 \\
\hline
\end{tabular}

${ }^{a}$ Values higher than 0 indicate that mineralization occurred.

This experiment clearly indicates the ultimate mineralization of the aromatic ring of $\left[\mathrm{C}_{12}-\mathrm{BA}^{*}\right]^{+}$, however, it did not allow precise monitoring of the mineralization kinetics due to lack of data points at the very beginning of the experiment (0-100 h; for details see Fig. S11, ESI), and a too high ${ }^{13} \mathrm{C}$ enrichment of $\mathrm{CO}_{2}$ far beyond the linear range of the applied GC-C-IRMS method due to low background concentration of non-labeled $\left[\mathrm{HCO}_{3}\right]^{-}$. Therefore, an additional experiment was run with a lower amount of the ${ }^{13} \mathrm{C}$-labeled HIL (1:9, $\left.\left[\mathrm{C}_{12}-\mathrm{BA}^{*}\right][\mathrm{MCPA}]:\left[\mathrm{C}_{12}-\mathrm{BA}\right][\mathrm{MCPA}]\right)$ monitoring the production of ${ }^{13} \mathrm{C}$-labeled $\mathrm{CO}_{2}$ for $100 \mathrm{~h}$.

The series of calculations to transform $\delta^{13} \mathrm{CO}_{2}$-values into actual mineralization of $\left[\mathrm{C}_{12}-\mathrm{BA}^{*}\right]^{+}$ ion given in percent are provided in the Experimental Section (see Eq. 2-4). The data (Fig. 2) shows that after a $45 \mathrm{~h}$ lag time, rapid mineralization of the $\left[\mathrm{C}_{12}-\mathrm{BA}^{*}\right]^{+}$cation started in the liquid microcosms. The data enabled the estimation of the mineralization half-life time, assuming zero order kinetics and not accounting for the lag phase for $\left[\mathrm{C}_{12}-\mathrm{BA}^{*}\right]^{+}$, to be 6.5 days. This is 6 days shorter compared to another report, which indicates a $\mathrm{DT}_{50}$ of 12.5 days for $[\mathrm{BA}][\mathrm{Cl}]$. This discrepancy is most likely due to not accounting for a slight decrease in the mineralization rate in the zero-order model. ${ }^{41}$

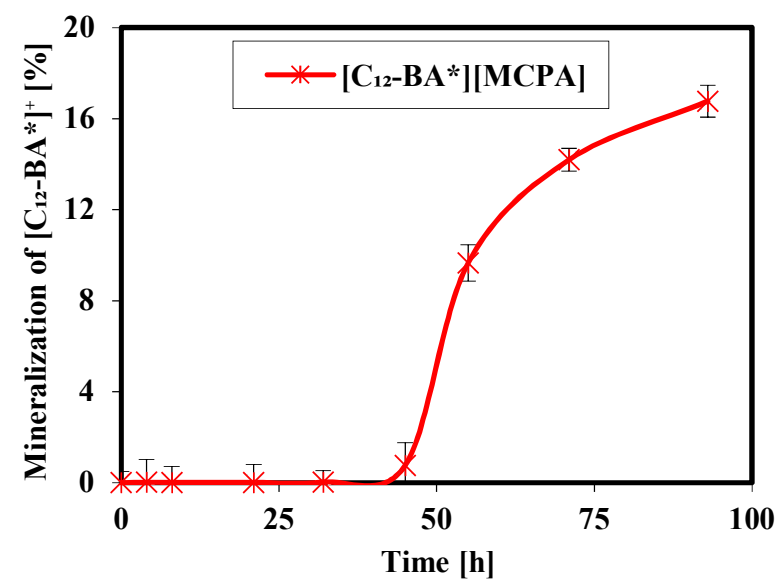


Fig. 2. Kinetics of mineralization of ${ }^{13} \mathrm{C}$-labeled $\left[\mathrm{C}_{12}-\mathrm{BA} \mathrm{A}^{*}\right]^{+}$in liquid microcosms amended with $\left[\mathrm{C}_{12}-\mathrm{BA}^{*}\right][\mathrm{MCPA}]$. The ${ }^{13} \mathrm{C}$-labeled $\left[\mathrm{C}_{12}-\mathrm{BA}^{*}\right][\mathrm{MCPA}]$ was 1:9 diluted with non-labeled $\left[\mathrm{C}_{12-}\right.$ $\mathrm{BA}][\mathrm{MCPA}]$ to allow monitoring mineralization.

\section{Mineralization in soil microcosms using the modified OECD 307 test}

In order to be able to compare the data from liquid and soil microcosms, we modified the OECD 307 test as follows: Soil microcosms were prepared using agricultural soil containing native soil microorganisms (for details see the Experimental Section Mineralization in soil microcosms), spiked with ${ }^{13} \mathrm{C}$-labeled or non-labeled target chemicals, and analyzed by determining the carbon isotope ratio $\left({ }^{13} \mathrm{C} /{ }^{12} \mathrm{C}\right)$ of $\mathrm{CO}_{2}$ generated by the microorganisms during mineralization of the ${ }^{13} \mathrm{C}$ labeled aromatic ring of the tested compounds by employing GC-C-IRMS (for details see Experimental Section). The results of the mineralization tests for soil microcosms (Table 3) revealed that the ${ }^{13} \mathrm{CO}_{2}$ originated almost exclusively from ${ }^{13} \mathrm{C}$-labeled $\left[\mathrm{MCPA}^{*}\right]^{-}$anions in $\left[\mathrm{C}_{12}-\right.$ $\mathrm{BA}]\left[\mathrm{MCPA}^{*}\right]$, while the $\left[\mathrm{C}_{12}-\mathrm{BA}^{*}\right]^{+}$cation underwent trace mineralization only.

Table 3. $\delta^{13} \mathrm{C}_{\mathrm{CO} 2}$-values [\%o] emitted in soil microcosm samples containing both ${ }^{13} \mathrm{C}$-labeled and unlabeled $\left[\mathrm{C}_{12}-\mathrm{BA}\right][\mathrm{MCPA}]$.

\begin{tabular}{l|ccccccc}
\hline Comp. & $\mathbf{0}$ & $\mathbf{5}$ & $\mathbf{1 0}$ & $\mathbf{2 0}$ & $\mathbf{3 0}$ & $\mathbf{4 0}$ & $\mathbf{7 3}$ \\
\hline$\left[\mathbf{C}_{\mathbf{1 2}}-\mathbf{B A}^{*}\right][\mathbf{M C P A}]$ & 6.2 & 45.8 & 86.8 & 40.3 & 32.7 & 37.0 & 83.5 \\
{$\left[\mathbf{C}_{\mathbf{1 2}}-\mathbf{B A}\right][\mathbf{M C P A}]$} & -2.8 & 453.7 & 5914.7 & $>10000$ & $>10000$ & $>10000$ & $>10000$ \\
{$\left[\mathbf{C}_{\mathbf{1 2}}-\mathbf{B A}\right][\mathbf{M C P A}]$} & -18.3 & -21.8 & -24.9 & -24.2 & -24.9 & -23.9 & -24.9 \\
{$\left[\mathbf{C}_{12}-\mathbf{B A}{ }^{*}\right][\mathbf{B r}]$} & -16.8 & 24.8 & 9.4 & 2.4 & 4.6 & 10.5 & 47.3 \\
{$\left[\mathbf{C}_{\mathbf{1 2}}-\mathbf{B A}\right][\mathbf{B r}]$} & -16.7 & -32.2 & -26.6 & -26.7 & -26.6 & -25.3 & -24.0 \\
\hline
\end{tabular}

This experiment clearly indicated the ultimate mineralization of [MCPA* $]^{-}$, however, it did not allow precise monitoring of the mineralization kinetics due to lack of data points in the initial days of the experiment as well as ${ }^{13} \mathrm{C}$-enriched $\mathrm{CO}_{2}$ far beyond the linear range of the applied GC-CIRMS method due to the low background concentration of non-labeled $\left[\mathrm{HCO}_{3}\right]^{-}$. Therefore, an additional experiment was run with lower amount of the ${ }^{13} \mathrm{C}$-labeled HIL $\left(1: 9\right.$, [C $\mathrm{C}_{12}$ BA][MCPA*]:[C $12-\mathrm{BA}][\mathrm{MCPA}])$ monitoring mineralization for $240 \mathrm{~h}$. Analogously as in the case of the liquid microcosms, the $\delta^{13} \mathrm{C}_{\mathrm{CO} 2}$-values were transformed into actual mineralization of [MCPA*]- ion given in percent (Experimental Section, Eq. 2-4). The lag phase in soil microcosms lasted ca. 7 days (Fig. 3) before mineralization of [MCPA* ${ }^{-}$started, which is consistent with the results obtained during the previous experiment (Table 3). Kinetic data enabled estimation of the mineralization half-life time using zero order kinetics and not accounting for the lag phase for 
[MCPA*] to be $\mathrm{DT}_{50}=32$ days. This is in accordance with the 28 day half-life time determined for $[\mathrm{HMCPA}]{ }^{42}$ Full degradation of the [MCPA*] anion would take ca. 58 days, which is also consistent with the 46-82 day degradation reported for the ${ }^{14} \mathrm{C}$-labeled sodium salt, [Na][MPCA] ${ }^{43}$

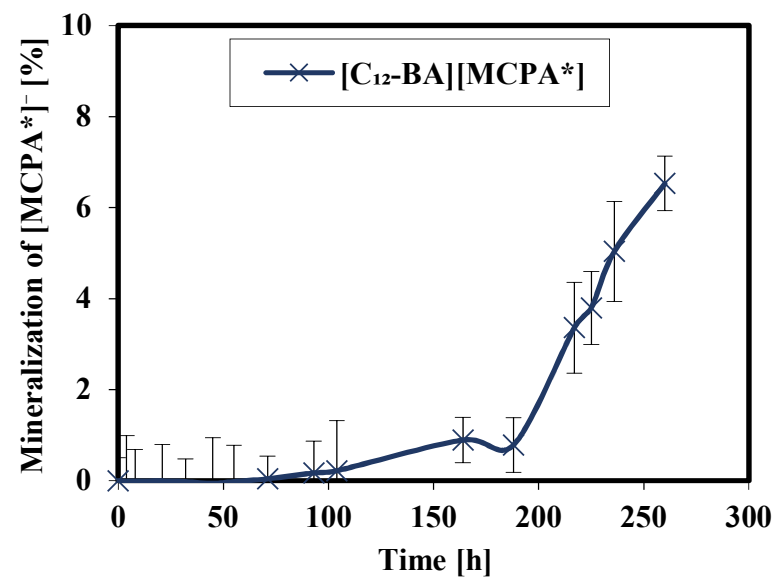

Fig. 3. Kinetics of mineralization of ${ }^{13} \mathrm{C}$-labeled $\left[\mathrm{MCPA}^{*}\right]^{-}$in soil microcosms amended with $\left[\mathrm{C}_{12}-\right.$ BA][MCPA*]. The ${ }^{13} \mathrm{C}^{*}$-labeled $\left[\mathrm{C}_{12}-\mathrm{BA}\right]\left[\mathrm{MCPA}^{*}\right]$ was 1:9 diluted with non-labeled $\left[\mathrm{C}_{12}-\right.$ $\mathrm{BA}][\mathrm{MCPA}]$ to allow monitoring mineralization.

\section{Primary biodegradation in liquid and soil microcosms}

As noted earlier, the lack of generated ${ }^{13} \mathrm{CO}_{2}$ indicates that a tested compound is not mineralized, however, it may still have undergone incomplete biotransformation leading to an accumulation of metabolites. Assessment of biotransformation was conducted by extraction of target compounds and potential metabolites using HPLC-MS/MS (for details see Experimental Section).

The concentrations of target compounds for the liquid microcosm (Fig. 4) revealed that two days were sufficient to transform the $\left[\mathrm{C}_{12}-\mathrm{BA}\right]^{+}$cation quantitatively. The sudden drop of $\left[\mathrm{C}_{12}-\mathrm{BA}\right]^{+}$concentration during the first $4 \mathrm{~h}$ might have resulted from adsorption on the biomass of the activated sludge. A recent report indicated that cationic surfactants are characterized by a strong sorption to microbial cells, especially in case of activated sludge (the sorption may reach up to $90 \%$ during the first minute).$^{51}$ The $[\mathrm{MCPA}]^{-}$anion was not subjected to biotransformation, its concentration remained constant during 73 days of the experiment. This is fully consistent with the data obtained for ${ }^{13} \mathrm{C}$-labeled [MCPA] $]^{-}$, where no mineralization was observed. 

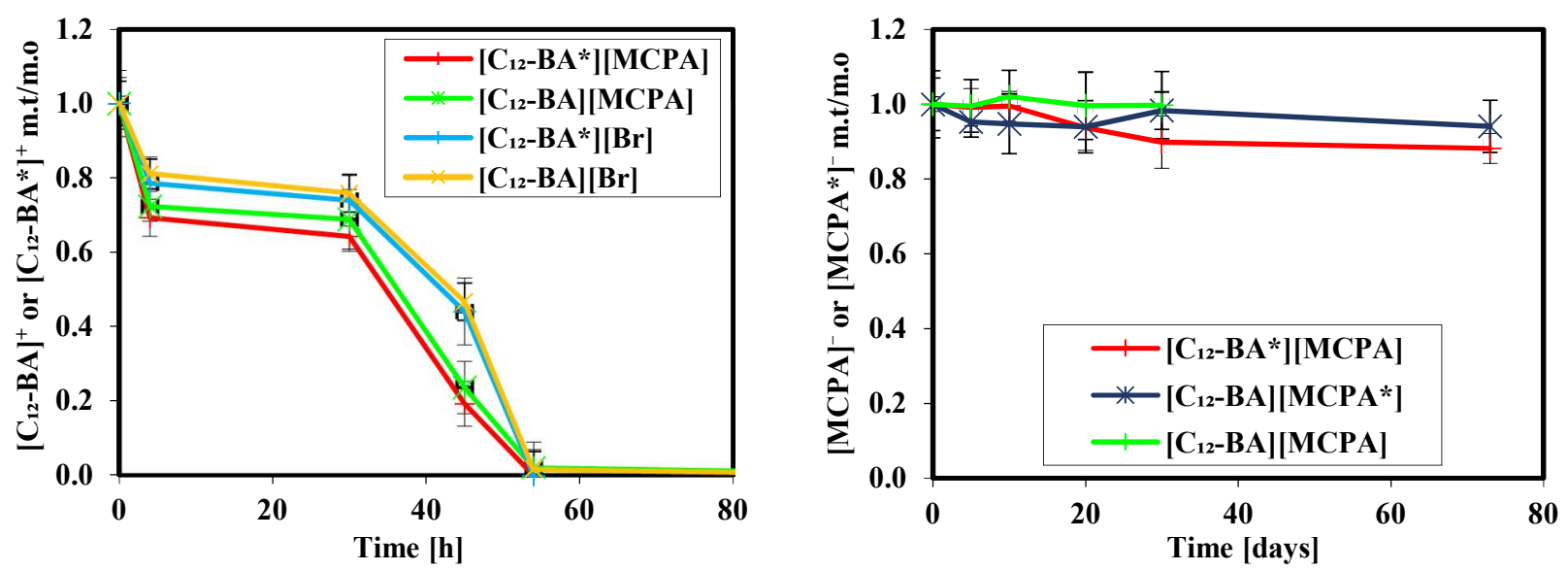

Fig. 4. Kinetics of biotransformation for $\left[\mathrm{C}_{12}-\mathrm{BA}\right]^{+}$or $\left[\mathrm{C}_{12}-\mathrm{BA}\right]^{+}$(left); and $[\mathrm{MCPA}]^{-}$or [MCPA* $^{-}$(right) in liquid microcosms.

In the case of the soil microcosms, biotransformation was observed for both the cation and the anion (Fig. 5). Complete removal of $\left[\mathrm{C}_{12}-\mathrm{BA}\right]^{+}$and $[\mathrm{MCPA}]^{-}$took place during 20 and 40 days, respectively. Bearing in mind the marginal ${ }^{13} \mathrm{C}$-enrichment of $\mathrm{CO}_{2}$ in the soil microcosm spiked with $\left[\mathrm{C}_{12}-\mathrm{BA}^{*}\right]^{+}$during the mineralization experiment (Table 2), the data suggests that only biotransformation took place and persistent metabolites were formed. As shown in Fig. 5, the $[\mathrm{MCPA}]^{-}$anion was degraded by soil microorganisms and later mineralized as observed by ${ }^{13} \mathrm{C}$ enrichment of $\mathrm{CO}_{2}$ (Table 3).
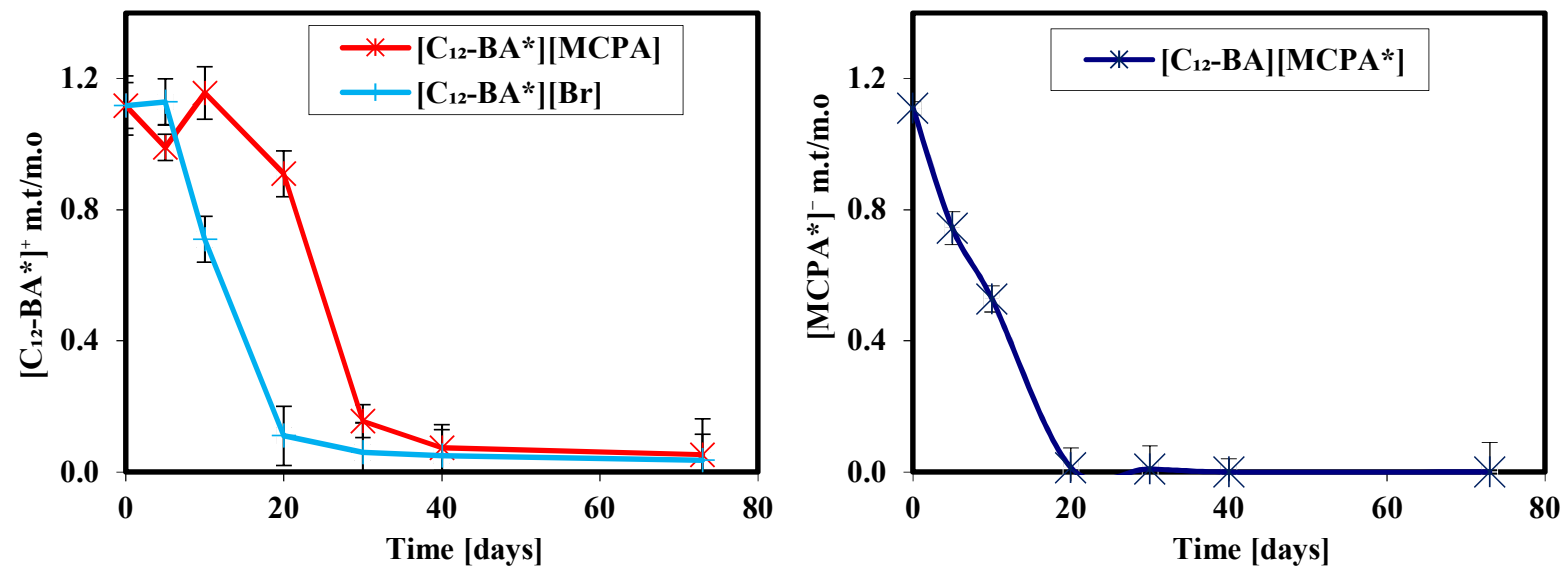

Fig. 5. Kinetics of biotransformation for $\left[\mathrm{C}_{12}-\mathrm{BA}^{*}\right]^{+}$cation (left); and $[\mathrm{MCPA}]^{-}$anion (right) in soil microcosms.

Assimilation of $\left[C_{12-B A}\right]^{+}$and $[M C P A *]^{-}$by the biomass 
Carbon assimilation by bacteria is a conversion process, in which the carbon is incorporated in microbial biomass by several metabolic pathways. ${ }^{52}$ This means that if bacteria are able to decompose ${ }^{13} \mathrm{C}$-labeled compounds, e.g., $\left[\mathrm{C}_{12}-\mathrm{BA}\right]^{+}$or $[\mathrm{MCPA}]^{-}$, the amino acids or fatty acids synthesized later by the bacteria will be enriched with ${ }^{13} \mathrm{C}$. Monitoring of phospholipids fatty acids (PLFAs) constituting the cell membranes enriched with ${ }^{13} \mathrm{C}$ during bacterial growth is among the most sensitive methods for quantifying carbon assimilation. ${ }^{53}$

Bearing in mind that according to Dungait et al. $2011^{54}$ there are specific fatty acids for Gram-

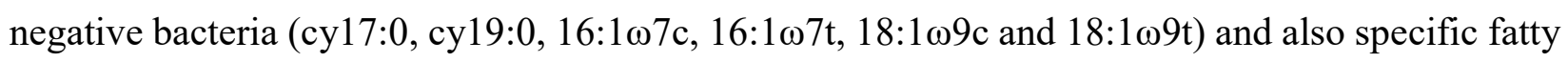
acids for Gram-positive bacteria (i15:0, a15:0, i16:0, and i17:0), we focused on possible ${ }^{13} \mathrm{C}$ enrichment of those fatty acids. Here, assessment of assimilation of the $\left[\mathrm{C}_{12}-\mathrm{BA}{ }^{*}\right]^{+}$cation and $\left[\mathrm{MCPA}^{*}\right]^{-}$anion by the biomass was conducted through phospholipid extraction for both variants (liquid and soil microcosms) at the end of the experiment according to common practice. ${ }^{53} \mathrm{After}$ methanolysis, the resulting fatty acid methyl esters were analyzed by GC-C-IRMS and GCxGCTOF-MS analysis to determine ${ }^{13} \mathrm{C}$-assimilation (for details see Experimental Section and Fig. S12-

\section{S14, Table S1, ESI).}

According to data shown in Fig. 6, the ${ }^{13} \mathrm{C}$-enrichment of the fatty acids i15:0, a15:0, 15:0,

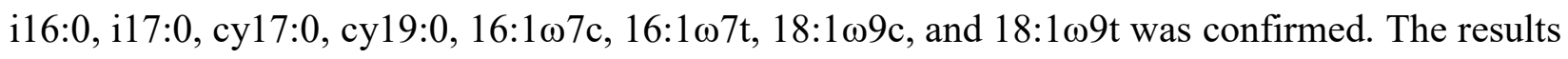
of the liquid microcosm study indicates that ${ }^{13} \mathrm{C}$ from ${ }^{13} \mathrm{C}$-labeled $\left[\mathrm{C}_{12}-\mathrm{BA}^{*}\right]^{+}$was assimilated by the bacteria and transformed into PLFAs constituting the bacterial membrane. Considering the previous mineralization and biotransformation studies, this is a further evidence for the ultimate degradation of HIL's cation in liquid microcosms. No ${ }^{13} \mathrm{C}$-enrichment in PLFAs was recorded for microcosms amended with the ${ }^{13} \mathrm{C}$-labeled [MCPA*] ${ }^{-}$anion, corresponding to the lack of ${ }^{13} \mathrm{C}$ enriched $\mathrm{CO}_{2}$.

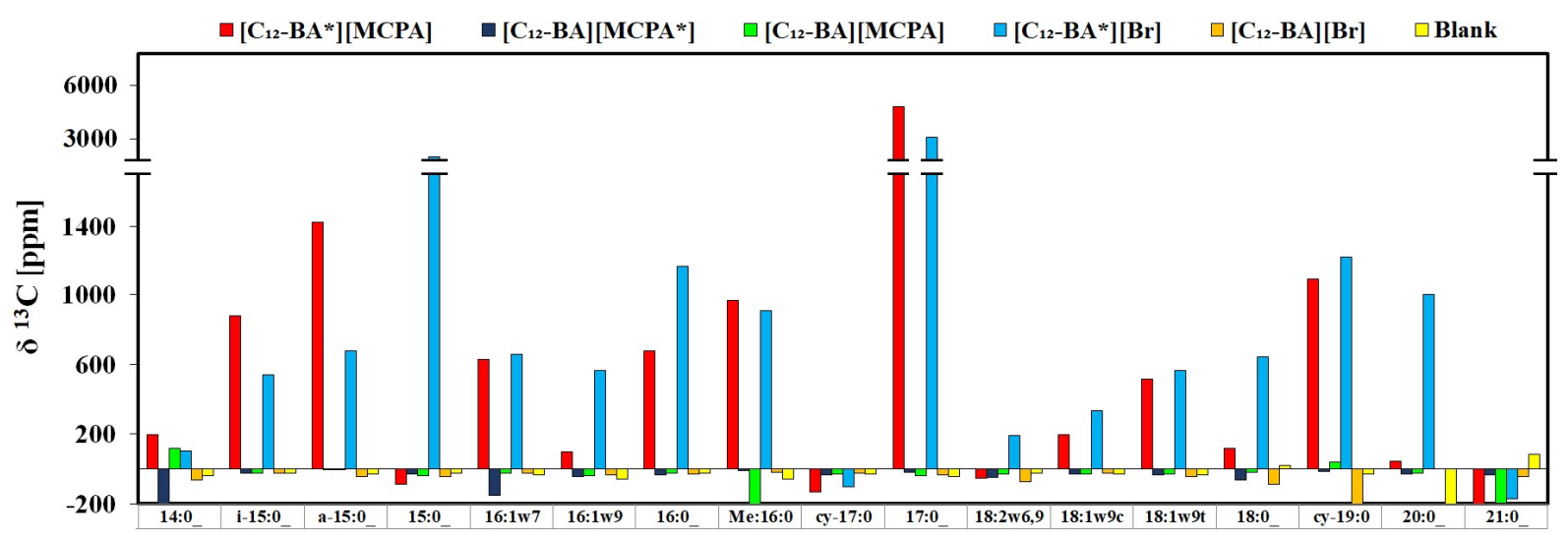


Fig. 6. $\delta^{13} \mathrm{C}$-values [\%o] of fatty acids from phospholipids (PFLAs) extracted from liquid microcosms.

Characteristic bacterial biomarkers of ${ }^{13} \mathrm{C}$-enriched fatty acids were found for the soil microcosm as well. However, the data (Fig. 7) shows ${ }^{13} \mathrm{C}$ from the ${ }^{13} \mathrm{C}$-labeled [MCPA*] ${ }^{-}$anion was assimilated by the bacteria while no ${ }^{13} \mathrm{C}$-enrichment in PLFAs from the ${ }^{13} \mathrm{C}$-labeled $\left[\mathrm{C}_{12}-\mathrm{BA}^{*}\right]^{+}$cation was observed. Thus, in soil microcosms only the HIL's anion was mineralized and assimilated by microorganisms.

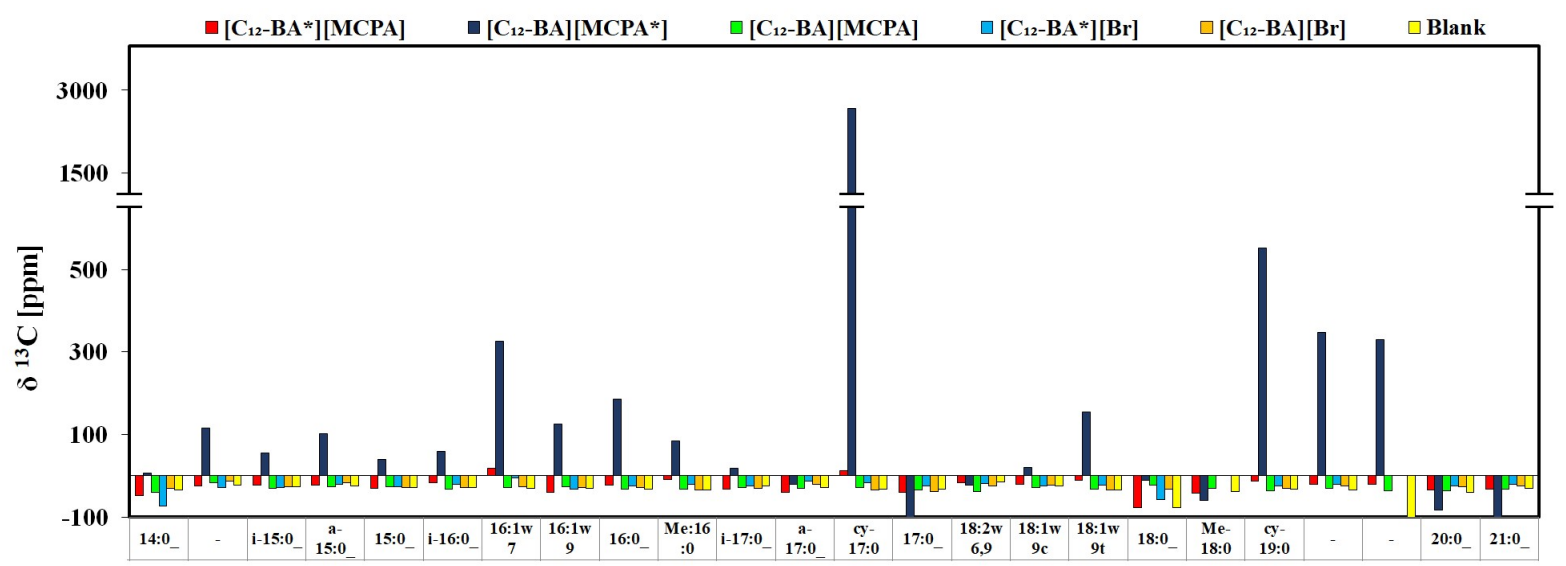

Fig. 7. $\delta^{13} \mathrm{C}$-values [\%o] of fatty acids (PFLAs) from phospholipids extracted from soil microcosms.

\section{Determination of metabolites in soil microcosms}

The metabolic pathways for both $\left[\mathrm{C}_{12}-\mathrm{BA}\right]^{+}$and $[\mathrm{MCPA}]^{-}$are well known. Based on the available literature, it was assumed that the $\left[\mathrm{C}_{12}-\mathrm{BA}\right]^{+}$cation is decomposed under oxic conditions via cleavage of the dodecyl-N forming protonated benzyldimethylamine ( 1 in Fig. 8). ${ }^{50}$ Then, the alkyl chain is enzymatically oxidized to dodecanoic acid (2). Protonated benzyldimethylamine may further undergo demethylation or debenzylation (3). In both cases benzoic acid (4) is formed (via benzaldehyde). Finally, benzoic acid undergoes further transformation (via protocatechuate or catechol) to 3-oxoadipate, which is either mineralized or assimilated. ${ }^{41,55}$

In case of the [MCPA] ${ }^{-}$anion, previous reports suggest that it is metabolized to glyoxylate and 2-methyl-4-chlorophenol [MCP] via cleavage of the ether bond. [MCP] is further degraded to 3oxoadipate and eventually both glyoxylate and 3-oxoadipate are either mineralized or assimilated. ${ }^{56}$ The mineralization and the biotransformation studies pointed our attention to the fate of the $\left[\mathrm{C}_{12}\right.$ - 
$\mathrm{BA}]^{+}$cation in soil microcosms only. After fast primary biodegradation, the further biotransformation of this cation stopped. Therefore, we focused on searching for possible $\left[\mathrm{C}_{12}\right.$ $\mathrm{BA}]^{+}$metabolites. Assessment of possible metabolites of $\left[\mathrm{C}_{12}-\mathrm{BA}^{*}\right]^{+}$in soil microcosms was conducted by extraction and characterization of starting compounds' possible metabolites using GCxGC-TOF-MS (for details see Experimental Section).

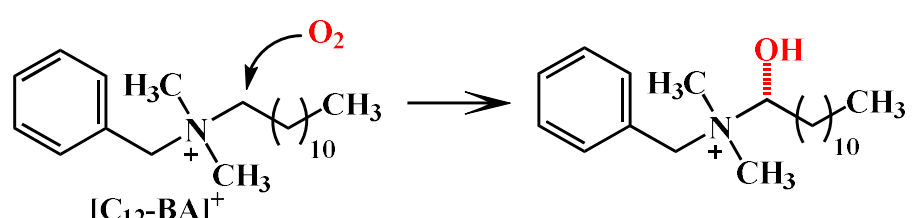<smiles>O=C(O)c1ccccc1</smiles>

(4)

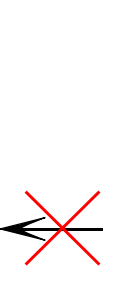

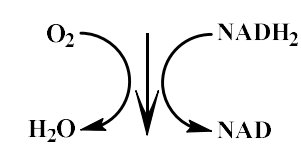

(3)

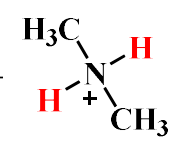

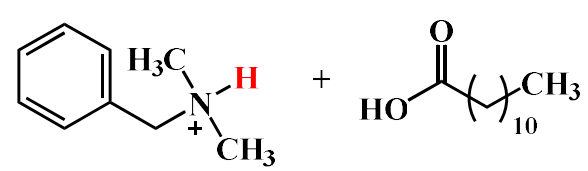

(1)

(2)

Fig. 8. Biotransformation pathway of the $\left[\mathrm{C}_{12}-\mathrm{BA}\right]^{+}$cation.

The obtained results (see Fig. S15, Table S2, ESI) revealed that the dealkylation of $\left[\mathrm{C}_{12}-\mathrm{BA}\right]^{+}$ took place as we confirmed the presence of the benzyldimethylamine (1), as well as decanoic acid (2). During the experiment no further degradation of $\mathbf{1}$ was observed. This observation is inconsistent with findings from the literature, where cationic surfactants like benzalkonium chloride (in contradiction to [MCPA] $]^{-}$) undergo strong sorption in the soil and should not be easily available for microorganisms ${ }^{57}$. However, in the course of our study ${ }^{13} \mathrm{C}$-labeled $\left[\mathrm{C}_{12}-\mathrm{BA}{ }^{*}\right]^{+}$and unlabeled $\left[\mathrm{C}_{12}-\mathrm{BA}\right]^{+}$were subjected to rapid biotransformation and then the process stopped. It is plausible that the resulting benzyldimethylamine was toxic for the microorganisms and its presence inhibited further progress of the biodegradation processes. ${ }^{55}$

\section{Conclusions}

The biodegradation test with water and activated sludge (OECD 301) for [ $\left.\mathrm{C}_{12}-\mathrm{BA}\right][\mathrm{MCPA}]$ revealed that significant mineralization of the $\left[\mathrm{C}_{12}-\mathrm{BA}\right]^{+}$cation with primary degradation occurred within less than $60 \mathrm{~h}$, whereas no microbial induced decomposition for the [MCPA]- anion was observed. The biodegradation test with soil (OECD 307) revealed the significant mineralization of 
the $[\mathrm{MCPA}]^{-}$anion and negligible mineralization of the $\left[\mathrm{C}_{12}-\mathrm{BA}\right]^{+}$cation. Furthermore, both ions, $\left[\mathrm{C}_{12}-\mathrm{BA}\right]^{+}$and $[\mathrm{MCPA}]^{-}$, were subjected to fast primary biodegradation within 40 days and 20 days, respectively. This means that $\left[\mathrm{C}_{12}-\mathrm{BA}\right]^{+}$, as well as $[\mathrm{MCPA}]^{-}$ions underwent biotransformation, however, only [MCPA $]^{-}$was completely mineralized to $\mathrm{CO}_{2}$, while degradation of $\left[\mathrm{C}_{12}-\mathrm{BA}\right]^{+}$cation stopped after formation of benzyldimethylamine.

The study on assimilation of the ${ }^{13} \mathrm{C}$-labeled HIL by microorganisms revealed that in aqueous tests only ${ }^{13} \mathrm{C}$ from the $\left[\mathrm{C}_{12}-\mathrm{BA}\right]^{+}$cation was incorporated by bacteria into PLFAs, whereas in soil tests only ${ }^{13} \mathrm{C}$ from $[\mathrm{MCPA}]^{-}$was utilized by the bacteria to synthesize PFLAs. This data suggests that mineralization of the cation and the anion proceeded differently depending on whether the experiments were carried out using activated sludge or soil microorganisms. This leads to the first conclusion that the OECD 301 tests currently used are not sufficient to fully understand the biodegradation of ILs. Consequently, prediction of biodegradation rate constant of HILs in terrestrial systems using data from biodegradation experiments performed in aqueous media, as suggested in the EPI Suite ${ }^{\mathrm{TM}}$ and applied in multimedia fate models, ${ }^{58,59}$ should be done with caution.

The microbial composition of activated sludge from wastewater treatment plants utilized within the OECD 301 test most probably is related to permanent contact with antibacterial compounds (among them cationic surfactants), and thus it is not surprising that these sludges were found to mineralize the $\left[\mathrm{C}_{12}-\mathrm{BA}\right]^{+}$cation. The lack of mineralization of the $[\mathrm{MCPA}]^{-}$anion observed here was reported previously, ${ }^{60}$ however this phenomenon has not been explained in detail regarding each ion of tested HILs separately.

On the other hand, the OECD 307 tests with agricultural soil microorganisms, were found to readily mineralize $[\mathrm{MCPA}]^{-}$, but the $\left[\mathrm{C}_{12}-\mathrm{BA}\right]^{+}$was only subjected to primary biodegradation. A plausible explanation for this could be that these soils are already in contact with commercial herbicides. These results indicate the significance of selecting either soil or sludge communities for biodegradation tests and how its selection can influence the final conclusions from a single study. Therefore, we recommend combining the assessment of primary biodegradation with mineralization tests in both environments (aqueous sludge and soil) and focusing on both ions independently. This strategy will shed new light on microbiological decomposition of ILs in general in the environment and could guide the synthesis of new ILs. Thus, potential risks of 
bioaccumulation of toxic metabolites could be avoided, which currently may go unnoticed by using conventional testing methods primarily designed for neutral compounds rather than organic salts.

Our approach with ${ }^{13} \mathrm{C}$-labeled target compounds provided direct evidence for the mineralization and assimilation of the different moieties of the investigated HIL, which without

${ }^{13} \mathrm{C}$-labeling, would have provided only limited and less sensitive results. The ${ }^{13} \mathrm{C}$-approach would also allow a more comprehensive evaluation of microorganisms or enzymatic pathways involved in the biodegradation of the ${ }^{13} \mathrm{C}$-labeled target compound using stable isotope probing of nucleic acids ${ }^{61,62}$ or proteins ${ }^{63}$. Due to these benefits, biodegradation test based on ${ }^{13} \mathrm{C}$-labeling should be applied in order to enable a thorough evaluation of the biodegradability of ILs.

\section{Experimental section}

\section{Materials}

${ }^{13} \mathrm{C}$-phenyl labeled benzyl bromide (99\%), benzyl bromide (98\%), N,N-dimethyldodecylamine (97\%), ${ }^{13}$ C-phenyl labeled 4-chloro-2-methylphenoxyacetic acid (99\%), 4-chloro-2methylphenoxyacetic acid (95\%), benzaldehyde (99\%), hydroxylamine hydrochloride (99\%), N,Obis(trimethylsilyl)trifluoroacetamide (99\%), silver nitrate (99\%), anhydrous sodium sulfate (99\%), dibasic sodium phosphate dehydrate (99\%), ammonium chloride (99.5\%), sodium chloride (99\%), dibasic potassium phosphate (99\%) were purchased from Sigma-Aldrich (Poznan, Poland) and used as obtained. Potassium hydroxide (85\%), sodium hydroxide (99\%), hydrochloric acid (36.5\%) and solvents (methanol (99.5\%), ethanol (96\%), dimethyl sulfoxide (DMSO) (99\%), acetonitrile (99.5\%), acetone (99.5\%), ethyl acetate (99\%), chloroform (98\%), dichloromethane (99.5\%), toluene (99.5\%), pentane (99\%), hexane (99\%) and diethyl ether (99\%)) were delivered by Avantor (Gliwice, Poland) and used without further purification.

\section{Synthesis of $\left[\mathrm{C}_{12}-\mathrm{BA} *[\mathrm{Br}]\right.$ and $\left[\mathrm{C}_{12}-\mathrm{BA}\right][\mathrm{Br}]$}

${ }^{13} \mathrm{C}$-labeled benzyldodecyldimethylammonium bromide $\left[\mathrm{C}_{12}-\mathrm{BA} *\right][\mathrm{Br}]$ and unlabeled benzyldodecyldimethylammonium bromide $\left[\mathrm{C}_{12}-\mathrm{BA}\right][\mathrm{Br}]$ were synthesized via the following quaternization reaction (Fig. S1, ESI). Dodecyldimetylamine $(0.005 \mathrm{~mol}),{ }^{13} \mathrm{C}$-labeled or unlabeled benzyl bromide $(0.0058 \mathrm{~mol})$ and $15 \mathrm{~mL}$ of acetonitrile were introduced into a round-bottom flask equipped with a Teflon-coated magnetic stirring bar. The reactants were stirred for $48 \mathrm{~h}$ at $60{ }^{\circ} \mathrm{C}$, and then the solvent was evaporated using a vacuum evaporator. Next, $5 \mathrm{~mL}$ of both, water and 
hexane was added, and the products were isolated via two phase extraction. The aqueous phase was washed 3 times with small amounts of hexane and after separation of phases water was evaporated in a rotary evaporator. Finally, products were dried under reduced pressure at $60{ }^{\circ} \mathrm{C}$ for $24 \mathrm{~h}$. The reaction yields amounted to 91 and $93 \%$, respectively. ${ }^{1} \mathrm{H}$ and ${ }^{13} \mathrm{C}$ NMR spectra of $\left[\mathrm{C}_{12}\right.$ $\mathrm{BA}][\mathrm{Br}]$ and $\left[\mathrm{C}_{12}-\mathrm{BA}^{*}\right][\mathrm{Br}]$ are provided in Fig. S3-S6 (ESI).

\section{${ }^{13} \mathrm{C}$-labeled benzyldodecyldimethylammonium bromide [C12-BA*][Br]}

${ }^{1} \mathrm{H} \mathrm{NMR}\left(\mathrm{CDCl}_{3}\right) \delta \mathrm{ppm}=0.85(\mathrm{t}, \mathrm{J}=6.9,3 \mathrm{H}), 1.26(\mathrm{~m}, 18 \mathrm{H}), 1.77(\mathrm{br} \mathrm{s}, 2 \mathrm{H}), 3.29(\mathrm{~s}, 6 \mathrm{H}), 3.52$ $(\mathrm{m}, 2 \mathrm{H}), 5.07(\mathrm{~s}, 2 \mathrm{H}) 7.42(\mathrm{~m}, 3 \mathrm{H}), 7.65(\mathrm{~d}, \mathrm{~J}=6.8,2 \mathrm{H}) ;{ }^{13} \mathrm{C} \mathrm{NMR}\left(\mathrm{CDCl}_{3}\right) \delta \mathrm{ppm}=14.19,22.75$, 23.02, 26.38, 29.33, 29.39, 29.45, 29.51, 29.65, 31.97, 49.73, 63.81, 67.43, 127.44, 129.28, 130.80, 133.34

\section{Benzyldodecyldimethylammonium bromide $[\mathrm{C} 12-\mathrm{BA}][\mathrm{Br}]$}

${ }^{1} \mathrm{H} \mathrm{NMR}\left(\mathrm{CDCl}_{3}\right) \delta \mathrm{ppm}=0.87(\mathrm{t}, \mathrm{J}=6.6,3 \mathrm{H}), 1.28(\mathrm{~m}, 18 \mathrm{H}), 1.74(\mathrm{~m}, 2 \mathrm{H}), 3.29(\mathrm{~s}, 6 \mathrm{H}), 3.51$ $(\mathrm{m}, 2 \mathrm{H}), 5.04(\mathrm{q}, \mathrm{J}=4.8,2 \mathrm{H}), 7.26\left(\right.$ under $\left.\mathrm{CDCl}_{3}, 2 \mathrm{H}\right), 7.45,7.64,7.85(3 \mathrm{x} \mathrm{br}, 3 \mathrm{H}) ;{ }^{13} \mathrm{C} \mathrm{NMR}$ $\left(\mathrm{CDCl}_{3}\right) \delta \mathrm{ppm}=14.23,22.79,23.05,26.40,29.36,29.43,29.48,29.55,29.68,32.00,49.85,63.85$, $63.96,67.37,67.71,126.86,126.94,127.22$, 127.30, 127.32, 127.39, 127.68, 127.77, 127.85, $128.76,128.86,129.24,129.29,129.35,129.67,129.71,129.75,129.79,130.42,130.49$, 130.56, $130.84,130.88,130.92$, 130.99, 131.27, 131.35, 132.86, 132.92, 132.95, 133.25, 133.30, 133.35, $133.71,133.75,133.80$.

\section{Synthesis of [C $\left.C_{12}-\mathrm{BA} *\right][M C P A],\left[C_{12}-B A\right][M C P A *]$, and [C $\left.12-B A\right][M C P A]$}

${ }^{13} \mathrm{C}$-labeled benzyldodecyldimethylammonium 4-chloro-2-methylphenoxyacetate $\left[\mathrm{C}_{12}\right.$ $\left.\mathrm{BA}^{*}\right][\mathrm{MCPA}]$, benzyldodecyldimethylammonium ${ }^{13} \mathrm{C}$-labeled 4-chloro-2-methylphenoxyacetate $\left[\mathrm{C}_{12}-\mathrm{BA}\right]\left[\mathrm{MCPA}^{*}\right]$ and benzyldodecyldimethylammonium 4-chloro-2-methylphenoxyacetate $\left[\mathrm{C}_{12}-\mathrm{BA}\right][\mathrm{MCPA}]$ were synthesized according to method described earlier ${ }^{44}$ in ion exchange reaction (Fig. S2, ESI). In a round-bottom flask equipped with dropping funnel and reflux condenser $0.005 \mathrm{~mol}$ of ${ }^{13} \mathrm{C}$-labeled or unlabeled (4-chloro-2-methylphenoxy)acetic acid, $5 \mathrm{~mL}$ of distilled water and $0.0051 \mathrm{~mol}$ of $\mathrm{KOH}$ was added. Next, the mixture was heated at $50{ }^{\circ} \mathrm{C}$ and stirred for $15 \mathrm{~min}$. Then a stoichiometric amount $(0.005 \mathrm{~mol})$ of ${ }^{13} \mathrm{C}$-labeled benzyldodecyldimethylammonium bromide $\left[\mathrm{C}_{12}-\mathrm{BA}^{*}\right][\mathrm{Br}]$ and unlabeled benzyldodecyldimethylammonium bromide $\left[\mathrm{C}_{12}-\mathrm{BA}\right][\mathrm{Br}]$ was added and the mixture was stirred for $30 \mathrm{~min}$ at room temperature. The resulting products were extracted from the aqueous phase 
with $5 \mathrm{~mL}$ of chloroform and washed with small amounts of distilled water until chloride or bromide ions were no longer detected using $\mathrm{AgNO}_{3}$ test. After removal of chloroform the product was dried under reduced pressure at $60{ }^{\circ} \mathrm{C}$ for $24 \mathrm{~h}$. The reaction yields amounted to $96 \%$ for $\left[\mathrm{C}_{12}-\right.$ $\left.\mathrm{BA}^{*}\right][\mathrm{MCPA}], 95 \%$ for $\left[\mathrm{C}_{12}-\mathrm{BA}\right]\left[\mathrm{MCPA}^{*}\right]$ and $98 \%$ for $\left[\mathrm{C}_{12}-\mathrm{BA}\right][\mathrm{MCPA}]$, respectively. The ${ }^{1} \mathrm{H}$ and ${ }^{13} \mathrm{C}$ NMR spectra of ${ }^{13} \mathrm{C}$-labeled products are provided in Fig. S7-S10 (ESI).

\section{${ }^{13} \mathrm{C}$-labeled benzyldodecyldimethylammonium 4-chloro-2-methylphenoxyacetate [ $\mathrm{C}_{12-}$ BA*][MCPA]}

${ }^{1} \mathrm{H} \mathrm{NMR}\left(\mathrm{CDCl}_{3}\right) \delta \mathrm{ppm}=0.87(\mathrm{t}, \mathrm{J}=7.0,3 \mathrm{H}), 1.26(\mathrm{~m}, 18 \mathrm{H}), 1.71(\mathrm{br} \mathrm{s}, 2 \mathrm{H}), 2.19(\mathrm{~s}, 3 \mathrm{H}), 3.14$ (s, 6H), $3.32(\mathrm{~m}, \mathrm{~J}=7.6,2 \mathrm{H}), 4.50(\mathrm{~d}, \mathrm{~J}=1.9,2 \mathrm{H}) 4.77(\mathrm{~d}, \mathrm{~J}=2.6,2 \mathrm{H}), 6.71(\mathrm{~d}, \mathrm{~J}=8.6,1 \mathrm{H}), 6.94$ $(\mathrm{d}, \mathrm{J}=8.6,1 \mathrm{H}), 7.00(\mathrm{~s}, 1 \mathrm{H}), 7.23(\mathrm{~m}, 2 \mathrm{H}), 7.31(\mathrm{~m}, 1 \mathrm{H}), 7.62(\mathrm{~m}, 1 \mathrm{H}), 7.71(\mathrm{~m}, 1 \mathrm{H}) ;{ }^{13} \mathrm{C} \mathrm{NMR}$ $\left(\mathrm{CDCl}_{3}\right) \delta \mathrm{ppm}=14.24,16.48,22.80,22.95,26.40,29.35,29.44,29.49,29.57,29.69,32.01,49.78$, $63.72,67.46,67.82,68.22,112.85,124.53,126.20,126.90,126.97,127.35,127.42,127.61$, $127.68,127.81,127.88,128.15,128.73,128.78,128.88,129.08,129.26,129.32,129.37,129.50$, $129.69,129.72,129.77,130.20,130.42,130.49,130.77,130.80,130.85,130.92,130.98,131.28$, $131.35,132.70,132.76,132.79,132.92,133.08,133.14,133.18,133.24,133.42,133.54,133.59$, $133.63,133.65,156.13,173.33$.

\section{Benzyldodecyldimethylammonium ${ }^{13} \mathrm{C}$-labeled 4-chloro-2-methylphenoxyacetate $\left[\mathrm{C}_{12}\right.$ - BA] $[$ MCPA*]}

${ }^{1} \mathrm{H} \mathrm{NMR}\left(\mathrm{CDCl}_{3}\right) \delta \mathrm{ppm}=0.88(\mathrm{t}, \mathrm{J}=7.0,3 \mathrm{H}), 1.27(\mathrm{~m}, 18 \mathrm{H}), 1.69(\mathrm{br} \mathrm{s}, 2 \mathrm{H}), 2.19(\mathrm{~d}, \mathrm{~J}=4.0$, $3 \mathrm{H}), 3.10(\mathrm{~s}, 6 \mathrm{H}), 3.27(\mathrm{~m}, 2 \mathrm{H}), 4.51(\mathrm{~d}, \mathrm{~J}=4.1,2 \mathrm{H}) 4.71(\mathrm{~s}, 2 \mathrm{H}), 6.52,6.74,6.80,6.92,7.14,7.19$ $(6 \mathrm{x}$ br, $3 \mathrm{H}), 7.44(\mathrm{~m}, 5 \mathrm{H}) ;{ }^{13} \mathrm{C} \mathrm{NMR}\left(\mathrm{CDCl}_{3}\right) \delta \mathrm{ppm}=14.24,16.32,16.66,22.80,22.94,26.42$, $29.35,29.44,29.49,29.57,29.70,32.01,49.78,63.74,67.71,68.34,112.32,112.35,112.80$, $112.85,112.89,113.34,123.83,123.90,124.36,124.87,125.67,125.71,125.74,126.13,126.16$, $126.19,126.24,126.27,126.66,126.69,126.72,128.15,128.63,129.15,129.38,129.70,129.73$, $130.20,130.68,133.14,155.63,155.66,156.20,156.70,156.74,156.76,173.33$.

\section{Methods}

\section{HIL Characterization}

${ }^{1} \mathrm{H}$ Nuclear magnetic resonance (NMR) spectra were recorded using AVANCE II Bruker and AVANCE III Bruker spectrometers operating with TMS as the internal standard at 400 and 500 MHz, respectively. ${ }^{13} \mathrm{C}$ NMR spectra were obtained with AVANCE III Bruker spectrometer at 125 
MHz. The water content, assayed in the obtained products by Karl Fisher titration using a TitroLine KF Trace coulometric titrator (SI Analytics, Germany, Mainz), was lower than 2000 ppm.

\section{Mineralization assessment}

\section{Mineralization in liquid microcosms}

The liquid microcosms were prepared in sterile $200 \mathrm{~mL}$ flasks (Glasgerätebau Ochs, Germany); $55 \mathrm{~mL}$ of sterile mineral medium $\left(\mathrm{Na}_{2} \mathrm{HPO}_{4} \times 2 \mathrm{H}_{2} \mathrm{O}-7.0 \mathrm{~g} / \mathrm{L} ; \mathrm{KH}_{2} \mathrm{PO}_{4}-2.8 \mathrm{~g} / \mathrm{L} ; \mathrm{NaCl}-0.5 \mathrm{~g} / \mathrm{L}\right.$; $\mathrm{NH}_{4} \mathrm{Cl}-1.0 \mathrm{~g} / \mathrm{L}$ ) was added to each flask. The activated sludge for biodegradation tests has been obtained from a municipal wastewater treatment plant in Szamotuły, Poland (GPS 52 $37^{\prime} 41.5^{\prime \prime} \mathrm{N}$, $\left.16^{\circ} 35^{\prime} 13.2^{\prime \prime} \mathrm{E}\right)$ and washed three times in sterile mineral medium before use. Initial cell density in flasks was set at approx. $10^{6}$ cells $/ \mathrm{cm}^{3}$ (determined with plastic Paddle Tester for aerobic bacteria, Hach, USA). After inoculation, the flasks were closed gas-tight with butyl rubber stoppers (Glasgerätebau Ochs, Germany) and aluminum crimps (VWR, Germany), which were autoclaved prior to experiment. Oxygen concentrations were determined by a non-invasive method using Fibox 3 Trace Oxygen Meter (PreSens Precision Sensing GmbH) with oxygen sensitive optode spots (SP-PSt3, PreSens Precision Sensing GmbH).

Microcosms spiking with HILs was performed with a glass chromatographic syringe. The following systems where analyzed: $\left[\mathrm{C}_{12}-\mathrm{BA} *\right][\mathrm{MCPA}],\left[\mathrm{C}_{12}-\mathrm{BA}\right]\left[\mathrm{MCPA}^{*}\right],\left[\mathrm{C}_{12}-\mathrm{BA}\right][\mathrm{MCPA}]$ (at concentration of approx. $1.7 \mathrm{mg} / \mathrm{mL}$ ), and $\left[\mathrm{C}_{12}-\mathrm{BA}^{*}\right][\mathrm{Br}],\left[\mathrm{C}_{12}-\mathrm{BA}\right][\mathrm{Br}]$ (at concentration of approx. $1.3 \mathrm{mg} / \mathrm{mL}$ ). Details are given in Table S3-S5 (ESI). The liquid microcosms were incubated at $20^{\circ} \mathrm{C}$, shaken on an orbital shaker at $150 \mathrm{rpm}$ in a semi dark room. All flasks were set up in triplicate, and additional flasks were set up for biotic (activated sludge prepared as described above, without tested HILs) and abiotic references (mineral medium supplemented with HILs, without activated sludge). The concentration and carbon isotope ratio of $\mathrm{CO}_{2}$ were analyzed in samples taken after $0,5,10,20,30,40$, and 73 incubation days.

The mineralization of $\left[\mathrm{C}_{12}-\mathrm{BA} *\right][\mathrm{MCPA}],\left[\mathrm{C}_{12}-\mathrm{BA}\right][\mathrm{MCPA} *]$ with lower ${ }^{13} \mathrm{C}$-amount was also studied within 100 hours (short-term experiment). Spiking was done at the same concentration, however, the ${ }^{13} \mathrm{C}$-labeled compound was diluted with the unlabeled one in a ratio of 1:9.

\section{Mineralization in soil microcosms}


Microcosms with $40 \mathrm{~g}$ of agricultural soil were prepared in previously autoclaved $200 \mathrm{~mL}$ serum flasks (Glasgerätebau Ochs, Germany). The agricultural soil, which was exposed to longterm herbicide treatment, was obtained from a seasonally tilled field of an experimental agricultural station - Institute of Plant Protection - Agricultural Experimental Station (Winna Góra, Poland, GPS $\left.52^{\circ} 12^{\prime} 29.5^{\prime \prime} \mathrm{N} 17^{\circ} 26^{\prime} 10.2^{\prime \prime E}\right)$. The soil was subjected to sieve analysis $(70 \%$ of sand, $30 \%$ of silt) and was classified as either silty loam or sandy loam. The soil was characterized in terms of: field moisture (water/dry soil 103.6 $\pm 1.8 \mu \mathrm{L} / \mathrm{g}$ d.m., water/wet soil $93.8 \pm 1.4 \mu \mathrm{L} / \mathrm{g}$ w.m.), porosity (317 $\pm 19 \mu \mathrm{L} / \mathrm{g} \mathrm{d.m.),} \mathrm{water} \mathrm{holding} \mathrm{capacity} \mathrm{(water/dry} \mathrm{soil} \mathrm{192.9 \pm 9.3 \mu L/g} \mathrm{d.m.)} \mathrm{and} \mathrm{soil} \mathrm{organic}$ matter (loss on ignition $19.6 \pm 1.1 \mathrm{mg} / \mathrm{g}$ d.m.). After being filled with soil, the flasks were closed gas-tight using sterile butyl rubber stoppers (Glasgerätebau Ochs, Germany) and aluminum crimps (VWR, Germany). For oxygen measurements, a Fibox 3 Trace Oxygen Meter was employed as described in the previous section.

Microcosms spiking with HILs was performed with glass chromatographic syringe. The following systems where analyzed: [C $\left.12-\mathrm{BA}^{*}\right][\mathrm{MCPA}],\left[\mathrm{C}_{12}-\mathrm{BA}\right]\left[\mathrm{MCPA}^{*}\right],\left[\mathrm{C}_{12}-\mathrm{BA}\right][\mathrm{MCPA}]$, $\left[\mathrm{C}_{12}-\mathrm{BA} *\right][\mathrm{Br}],\left[\mathrm{C}_{12}-\mathrm{BA}\right][\mathrm{Br}]$ at concentration of approx. $100 \mu \mathrm{mol} / \mathrm{kg}$. Details are given in Table S6-S11 (ESI). The soil microcosms were incubated at $20^{\circ} \mathrm{C}$ in a semi dark room. All flasks were prepared in triplicate, and additional flasks were prepared for biotic (agricultural soil, without tested HILs) and abiotic (soil sterilized in an oven at $105^{\circ} \mathrm{C}$ for $6 \mathrm{~h}$ and spiked with HILs, the sterility was checked by plating) references. The concentration and carbon isotope ratio of $\mathrm{CO}_{2}$ were analyzed in samples taken after $0,5,10,20,30,40$, and 73 incubation days. In the second experiment, the mineralization of $\left[\mathrm{C}_{12}-\mathrm{BA}^{*}\right][\mathrm{MCPA}],\left[\mathrm{C}_{12}-\mathrm{BA}\right]\left[\mathrm{MCPA}^{*}\right]$ at lower ${ }^{13} \mathrm{C}$-amount was studied within 260 hours (short-term experiment). Spiking was done with new solutions in which the ${ }^{13} \mathrm{C}$-labeled compound was diluted with the unlabeled one in a ratio of 1:9.

\section{Mineralization assessment - Measurements of carbon isotope ratios $\left({ }^{13} \mathrm{C}^{12} \mathrm{C}\right)$ of $\mathrm{CO}_{2}$}

The following protocol was employed for sampling during the experiments. First, a $10 \mathrm{~mL}$ headspace vial was flushed with nitrogen and closed immediately with an aluminum crimp with PTFE coated septum. Then, $10 \mathrm{~mL}$ of the gas was withdrawn from the vial by a $10 \mathrm{~mL}$ syringe. Next, $10 \mathrm{~mL}$ of the headspace from the microcosms was withdrawn with a disposable $10 \mathrm{~mL}$ syringe, transferred into the headspace vial which was stored in a refrigerator $\left(5^{\circ} \mathrm{C}\right)$ before analysis. After headspace sampling, the microcosms were supplemented with $10 \mathrm{~mL}$ of $\mathrm{CO}_{2}$-free 
air with $10 \mathrm{~mL}$ syringe passed through $0.2 \mu \mathrm{m}$ sterile PTFE syringe filter. If needed, pure oxygen was applied to re-supplement cultures. The samples were collected at days 0, 5, 10, 20, 40 and 73 in the first experiment. For day 0, sampling was performed immediately after preparation of the microcosms, which was approx. 2 hours after spiking.

For short-term experiments, measurements of carbon isotope ratios $\left({ }^{13} \mathrm{C} /{ }^{12} \mathrm{C}\right)$ of $\mathrm{CO}_{2}$ were done by direct collection and injection of the headspace into the instrument. The samples were collected in 4-hours intervals during the first day of incubation, and in one day intervals for the following few days of the experiment.

Carbon isotope ratios of $\mathrm{CO}_{2}$ emitted in samples were determined by employing a GC-C-IRMS (gas chromatography - combustion - isotope ratio mass spectrometry)instrument consisting of: a gas chromatograph (GC; Agilent 7890) coupled via a combustion device (C; Thermo Fisher Scientific) to an isotope ratio mass spectrometer (IRMS; Thermo Fisher Scientific MAT 253). An aliquot of the sample, ranging from 100 to $1000 \mu \mathrm{L}$ depending on the expected $\mathrm{CO}_{2}$ concentration, was manually injected with a gas-tight syringe (Hamilton, USA) into the injector of the GC operating at $250{ }^{\circ} \mathrm{C}$ and split ratio of 1:5. Chromatographic separation of $\mathrm{CO}_{2}$ was performed isothermally at $45{ }^{\circ} \mathrm{C}$ on PoraPLOT Q column ( $25 \mathrm{~m}, 0.32 \mathrm{~mm} \mathrm{ID,} 10 \mu \mathrm{m}$ film), and the flow of helium, serving as a carrier gas, of $2 \mathrm{~mL} / \mathrm{min}$. The carbon isotope ratios $\left({ }^{13} \mathrm{C} /{ }^{12} \mathrm{C}\right)$ are reported in the $\delta^{13} \mathrm{C}$-notation relative to the Vienna Pee Dee Belemnite (V-PDB) standard - (Eq. 1): ${ }^{64}$

$$
\delta^{13} C[\% 0]=\frac{R_{S}}{R_{S t d}}-1
$$

where $R_{S}$ and $R_{\text {Std }}$ are the ratios of the heavy isotope to the light isotope $\left({ }^{13} \mathrm{C} /{ }^{12} \mathrm{C}\right)$ in the sample and in the international standard, respectively. Because variations in natural isotope abundance are typically small, $\delta$-values are mostly reported in per mil (\%o). Samples were measured in three replicates.

\section{Determination of mineralization}

Based on the area of the peak at $0 \mathrm{~h}$ and the assumption that the concentration at that point was equal to $402.8 \mathrm{ppm}$ (for June 2015, http://www.esrl.noaa.gov/gmd/ccgg/trends/), the total $\mathrm{CO}_{2}$ concentration in the headspace [ppm] was calculated. Based on the $\delta^{13} \mathrm{C}_{\mathrm{CO} 2}$-value, the percentage of ${ }^{13} \mathrm{CO}_{2}$ was calculated (Eq. 2). ${ }^{65}$ The ${ }^{13} \mathrm{C}$ abundance of $\mathrm{CO}_{2}$ was determined by measuring the ion intensities at $m / z 44$ and 45 (Eq. 3). 


$$
\text { atom } \%{ }^{13} \mathrm{C}=\frac{\left[{ }^{13} \mathrm{CO}_{2}\right]}{\left[{ }^{12} \mathrm{CO}_{2}\right]+\left[{ }^{13} \mathrm{CO}_{2}\right]} \cdot 100=\frac{I_{45}}{I_{44}+I_{45}} \cdot 100
$$

where $I_{44}$ and $I_{45}$ are the intensity of the peaks at $m / z 44$ and 45 , respectively. If $R^{\prime}=I_{44} / I_{45}$ then:

$$
\text { atom } \%{ }^{13} \mathrm{C}=\frac{100}{R^{\prime}+1}
$$

To convert $\delta^{13} C_{V-P D B}$ to atom $\%(\mathrm{AP}){ }^{13} C$ :

$$
A P^{13} C=\frac{100}{\frac{1}{\left(\frac{\delta^{13} C}{1000}+1\right) \cdot R_{V-P D B}}+1}
$$

where $\delta^{13} C$ is the measured $\delta^{13} C_{C O 2}$-value and $R_{V-P D B}$ is the carbon isotope ratio $\left({ }^{13} \mathrm{C} /{ }^{12} \mathrm{C}\right)$ of VPDB with $0.0111802 .^{66}$

Based on the multiplication of atom $\%{ }^{13} \mathbf{C}$ at $\mathbf{0 ~} \mathbf{h}$ - which is assumed to be a background level of ${ }^{13} \mathrm{C}$ content - and total $\mathbf{C O}_{2}$ concentration, the concentration of ${ }^{13} \mathrm{CO}_{2}$ derived from the tested compounds in the headspace [ppm] was calculated (Eq. 4). Next, the content of ${ }^{13} \mathrm{CO}_{2}$ derived from HIL dissolved in water phase $[\mathrm{nmol} / \mathrm{ml}]$ was calculated based on the Henry's Law (Eq. 5):

$$
p=k_{H} c
$$

where $\mathrm{p}$ - the content of ${ }^{13} \mathrm{CO}_{2}$ derived from HIL dissolved in water phase $[\mathrm{nmol} / \mathrm{mL}], \mathrm{k}_{\mathrm{H}}=0.0345$ $\left[\mathrm{mol} / \mathrm{m}^{3} \mathrm{~Pa}\right]^{67}, \mathrm{c}-$ mole fraction.

Then, the $\left[\mathrm{H}^{13} \mathrm{CO}_{3}\right]^{-}$derived from HIL concentration $[\mathrm{nmol} / \mathrm{mL}]$ was calculated based on the dissolved ${ }^{13} \mathrm{CO}_{2}$ derived from HIL concentration in water and $\mathrm{pK}_{\mathrm{a}}=6.37$ (Eq. 6). The concentration of $\left[\mathrm{CO}_{3}\right]^{2-}$ at $\mathrm{pH}$ of 7 is low and was neglected.

$$
\left[\mathrm{H}^{13} \mathrm{CO}_{3}\right]^{-}=\frac{p \cdot K_{a}}{\left[H^{+}\right]}
$$

To calculate the amount of ${ }^{13} \mathrm{C}$ derived from HIL in the headspace [nmol], the concentration of ${ }^{13} \mathrm{C}$ derived from HIL in the headspace was divided by the volume of the headspace $(140 \mathrm{~mL}=$ $6.25 \mathrm{mmol}]$. In order to calculate the total amount of ${ }^{13} \mathrm{CO}_{2}$ and $\left[\mathrm{H}^{13} \mathrm{CO}_{3}\right]^{-}$derived from HIL dissolved in the water phase, their concentrations were multiplied by the volume of the water phase 
$(60 \mathrm{ml})$. As a result, the total amount of ${ }^{13} \mathrm{C}$ products of HIL mineralization could be calculated as the sum of all the above mentioned [nmol].

Finally, this allowed to calculate the extent of mineralization [\%] based on the initial amount of ${ }^{13} \mathrm{C}$-labeled compound (Eq. 7). ${ }^{29,30}$

$$
\text { mineralization }[\%]=\frac{\text { total amount of }{ }^{13} C \text { products of HIL }}{\text { initial }{ }^{13} C \text { content }}
$$

where the initial ${ }^{13} \mathrm{C}$ content is $3600 \mathrm{nmol}$.

\section{Kinetic model for mineralization}

To compare mineralization kinetics with published values, a nonlinear regression analysis was performed on the cumulative mineralization curves, using the fitting feature of SigmaPlot, ver. 11 (Systat Software, Inc., San Jose, CA). The mineralization data exceeding zero values were fitted using an exponential growth first order model, chosen as it performed better based on $\mathrm{F}$ test $(\mathrm{P}<0.05)$ when compared to zero-order or logarithmic kinetic models (not shown).

\section{Primary biodegradation - ion removal assessment}

\section{Liquid microcosms}

Each time, just after collection of the headspace samples for mineralization measurements, $1 \mathrm{~mL}$ subsamples of the liquid phase were collected with disposable syringe and transferred into $1.5 \mathrm{~mL}$ centrifuge tubes (or glass vials in case of the sterile controls containing no biomass). The samples were centrifuged $\left(4^{\circ} \mathrm{C}, 4500 \mathrm{rpm}, 15 \mathrm{~min}\right)$ and the aliquots were stored frozen for analysis. After defrosting, the samples were diluted 50-fold with water and subsequently 10 -fold with water - methanol mixture $(1: 4 \mathrm{v} / \mathrm{v})$. Such dilution resulted in the final concentration of the cation and anion equal to $0.2 \mathrm{nmol} / \mathrm{mL}$. Then the samples were subjected to HPLC-MS/MS analysis for determination of cations and anions. For quantitative purposes, the same solutions that were used for microcosms spiking were diluted accordingly and served as external standards. The recovery of cation and anion from the sterile controls was quantitative, so it was confirmed that no abiotic degradation took place.

\section{Soil microcosms}

It was not possible to collect subsamples of soil in a manner that would not disturb the microcosm, therefore parallel microcosms were prepared and frozen at the day of sampling. For 
extraction of the test compounds from soil, the following procedure was employed. The sample was defrosted, then $35 \mathrm{~mL}$ of anhydrous ethanol was added, and samples were shaken vigorously, then sonicated in a water bath at $40{ }^{\circ} \mathrm{C}$ for 10 minutes. Samples were left to cool to the ambient temperature and allowed for sedimentation. Extracts were transferred into a $50 \mathrm{~mL}$ centrifuge tube. The first fraction of the extract was centrifuged for $5 \mathrm{~min}$ at $4500 \mathrm{rpm}$, and the supernatant was transferred into a $100 \mathrm{~mL}$ volumetric flask. Extraction was carried out in triplicates and then extracts were combined. The pellet remaining in the centrifuge vial was extracted with $2.5 \mathrm{~mL}$ of anhydrous ethanol. Finally all extracts were combined and the volume was adjusted to $100 \mathrm{~mL}$ with anhydrous ethanol. An aliquot of the extract was passed through a $0.45 \mu \mathrm{m}$ PTFE syringe filter collecting the filtrate into $10 \mathrm{~mL}$ glass vial. For determination of the residual anion and cation, an aliquot of the extract was diluted 40-fold with anhydrous ethanol, and subsequently 5-fold with water - anhydrous methanol mixture $(1: 4 \mathrm{v} / \mathrm{v})$. Such dilution resulted in the final concentration of the cation and anion equal to $0.2 \mathrm{nmol} / \mathrm{mL}$. For quantitative analysis six standard samples of $4 \mathrm{~g}$ field-moist soil were spiked with a solution of [ $\left.\mathrm{C}_{12}-\mathrm{BA}\right][\mathrm{MCPA}]$ that was used for the experiment at the level of $10 \%, 50 \%$ and $100 \%$ of the initial content (volume of 12,60 and $120 \mu \mathrm{L}$, respectively). Then these samples were subjected to the developed extraction protocol and analyzed. A standard solution prepared via proper dilution served for comparison and calculation of the extraction efficiency. The recovery of both cations and anions from sterile soil microcosms after 73 days was quantitative, which confirmed the sterility of the microcosms and applicability of the developed sample preparation protocol (for details see Fig. S16-S19, ESI).

\section{Primary biodegradation assessment -HPLC-MS/MS characteristics}

The chromatographic system UltiMate 3000 RSLC from Dionex (Sunnyvale, CA, USA) was used. Two $\mu \mathrm{L}$ samples were injected into an octadecyl Hypersil GOLD column (100 $\mathrm{mm} \times$ $2.1 \mathrm{~mm}$ I.D.; $1.9 \mu \mathrm{m}$ ) from Thermo Scientific (Waltham, MA, USA) with a $2.1 \mathrm{~mm}$ I.D. filter cartridge $(0.2 \mu \mathrm{m})$ from the same supplier. The mobile phase employed in the analysis consisted of $5 \mathrm{mmol} \mathrm{L}^{-1}$ ammonium acetate in water and methanol at a flow rate of $0.2 \mathrm{~mL} \mathrm{~min}^{-1}$. The analysis was performed using a gradient elution with the organic modifier percentage increasing from $85 \%$ to $100 \%$ in 2 minutes and after that maintained at $100 \%$ for 2 minutes. The eluent from the LC column was directed to the API 4000 QTRAP triple quadrupole mass spectrometer from AB Sciex (Foster City, CA, USA) through the electrospray ionization source. The source operated in a 
positive ion mode for the determination of cations and in a negative ion mode for the determination of anions. The dwell time for each mass transition detected in the MS/MS multiple reaction monitoring mode was set to $200 \mathrm{~ms}$. The following mass spectrometer settings were used for the analysis: curtain gas 10 psi, nebulizer gas 40 psi, auxiliary gas $40 \mathrm{psi}$, temperature $400{ }^{\circ} \mathrm{C}$ and collision gas medium. The ion spray voltage was $4500 \mathrm{~V}$ for cations and $-4500 \mathrm{~V}$ for anions. The declustering potential was $50 \mathrm{~V}$ for cations and $-50 \mathrm{~V}$ for anions. The detected mass transitions and collision energy of each analyte are summarised in Table 4.

Table 4. Parameters of mass spectrometric detection characteristic to the particular analytes. MRM 1 - analytical multiple reaction monitoring transition, MRM 2 - confirmatory multiple reaction monitoring transition.

\begin{tabular}{c|cccc}
\hline Analyte & $\begin{array}{c}\text { MRM 1 } \\
\mathbf{m} / \mathbf{z}\end{array}$ & $\begin{array}{c}\text { Collision energy } \\
{[\mathbf{e V}]}\end{array}$ & $\begin{array}{c}\text { MRM 2 } \\
\mathbf{m} / \mathbf{z}\end{array}$ & $\begin{array}{c}\text { Collision energy } \\
{[\mathbf{e V}]}\end{array}$ \\
\hline$\left[\mathrm{C}_{12}-\mathrm{BA}\right]$ & $304 \rightarrow 91$ & 35 & $304 \rightarrow 212$ & 29 \\
{$\left[\mathrm{C}_{12}-\mathrm{BA}{ }^{*}\right]$} & $310 \rightarrow 97$ & 35 & $310 \rightarrow 212$ & 29 \\
{$[\mathrm{MCPA}]$} & $199 \rightarrow 141$ & -23 & $199 \rightarrow 155$ & -15 \\
{$\left[\mathrm{MCPA}^{*}\right]$} & $205 \rightarrow 147$ & -23 & $193 \rightarrow 161$ & -15 \\
\hline
\end{tabular}

\section{Assimilation of ${ }^{13} \mathrm{C}$-labeled $\left[\mathrm{C}_{12}-\mathrm{BA}^{*}\right]^{+}$and $\left[\mathrm{MCPA}^{*}\right]^{-}$into the biomass}

After termination of the mineralization experiment the assimilation of the investigated compounds into the biomass was evaluated. For this purpose the phospholipid fatty acids (PLFA) constituting the cell membranes were extracted, derivatized via alkaline methanolysis and subjected to GC-C-IRMS analysis. In general the sample preparation protocol developed by Bombach et al. $2010^{53}$ was employed, which is based on the fundamental work of Bligh \& Dyer 1959. ${ }^{68}$ Modifications were however made and hence the procedures employed are described below in detail. All the glassware was rinsed with acetone, dried under a fume hood, wrapped with aluminum foil and heated at $450{ }^{\circ} \mathrm{C}$ for 4 hours. In the case of disposable materials (GC vials and Pasteur pipettes) the acetone rinsing step was omitted. Only screw caps with PTFE coated septum were used and these were rinsed with acetone, dried and stored wrapped with aluminum foil. 0.05 $\mathrm{M}$ phosphate buffer $\left(\mathrm{KH}_{2} \mathrm{PO}_{4} / \mathrm{Na}_{2} \mathrm{HPO}_{4}\right)$ was prepared freshly before use. $8.7 \mathrm{~g}$ of $\mathrm{Na}_{2} \mathrm{HPO}_{4}$ was dissolved in 1 liter of bi-distilled water and adjusted to $\mathrm{pH} 7.4$ with few drops of concentrated $\mathrm{HCl}$. Then, the solution was passed through $0.2 \mu \mathrm{m}$ filter (Whatman International Ltd., Maidstone, UK) 
and collected in screw capped flask. Later, $50 \mathrm{~mL}$ of $\mathrm{CHCl}_{3}$ was added to the flask and after gentle shaking the solution was left for phase separation in the fridge overnight.

\section{Liquid microcosms}

Flasks with liquid microcosms were vortexed to suspend the biomass. The stopper was removed and approx. $30 \mathrm{~mL}$ of the culture was centrifuged in a $50 \mathrm{~mL}$ centrifuge tube for $15 \mathrm{~min}$ at 6000 rpm. The supernatant was subsequently discarded. The same procedure was repeated for the remaining approx. $30 \mathrm{~mL}$ of the culture. Both biomass pellets were vortexed with $2 \mathrm{~mL}$ aliquot of phosphate buffer. Then the biomass was combined in $45 \mathrm{~mL}$ glass vial with PTFE cap. Next, 10 $\mathrm{mL}$ of methanol and $5 \mathrm{~mL}$ of chloroform were added and the vial was vortexed for 5 minutes at level 6. The vial was sonicated for 6 minutes at level 6 and shaken overnight at $100 \mathrm{rpm}$ and $30{ }^{\circ} \mathrm{C}$. In the next step, $5 \mathrm{~mL}$ of chloroform and $5 \mathrm{~mL}$ of nanopure water were added. Subsequently, the sample was vortexed for 2 minutes at level 6 and centrifuged for $20 \mathrm{~min}$ at $4{ }^{\circ} \mathrm{C}$ and $2000 \mathrm{rpm}$. The organic layer was collected with a Pasteur pipette and transferred into a $10 \mathrm{~mL}$ vial with PTFE cap. The solvent was finally evaporated to dryness under a gentle stream of nitrogen. Subsequently, the derivatization was performed (see below - derivatization section).

\section{Soil microcosms}

A modified protocol reported by Bossio \& Snow $1998^{69}$ was employed. $4.0 \mathrm{~g}$ of wet soil from the microcosm was transferred to $10 \mathrm{~mL}$ glass vial. $1.5 \mathrm{~mL}$ of phosphate buffer was added and the sample was vortexed for 1 minute at level 6 . Next, $5.5 \mathrm{~mL}$ of anhydrous methanol and $2.5 \mathrm{~mL}$ of anhydrous chloroform were added, and the sample was again vortexed at level 6. If one phase was created (if not, methanol was added), the sample was sonicated for 6 minutes, then shaken for 2 hours at $100 \mathrm{rpm}$ and $30{ }^{\circ} \mathrm{C}$ while vortexed every $30 \mathrm{~min}$ for $30 \mathrm{~s}$. Then sample was centrifuged for $15 \mathrm{~min}$ at $2000 \mathrm{rpm}$ and $4{ }^{\circ} \mathrm{C}$, and the extract was collected with a Pasteur pipette, transferred into a $30 \mathrm{~mL}$ glass vial with PTFE cap. The residual pellet was mixed with $2.0 \mathrm{~mL}$ of buffer, 2.5 $\mathrm{mL}$ of $\mathrm{CHCl}_{3}$ and $5 \mathrm{~mL}$ of $\mathrm{MeOH}$ and vortexed, then shaken overnight at $100 \mathrm{rpm}$ and $30{ }^{\circ} \mathrm{C}$. The sample was again centrifuged for $15 \mathrm{~min}$ at $2000 \mathrm{rpm}$ and $4{ }^{\circ} \mathrm{C}$, and the extract was collected and combined with the previous extract. The extract was divided into two phases by addition of $5 \mathrm{~mL}$ of water and $5 \mathrm{~mL}$ of $\mathrm{CHCl}_{3}$ and allowed for overnight phase separation. The chloroform layer was collected with a Pasteur pipette and transferred to a $10 \mathrm{~mL}$ glass vial. The solvent was evaporated 
under a gentle stream of nitrogen. Subsequently, the derivatization was performed (see below derivatization section).

\section{Derivatization}

For GC analysis the extracted lipids were converted into more volatile and less polar methyl ester derivatives. For this purpose; mild alkaline methanolysis was selected; which enables for conversion of only esterified acids and minimizes the risk of undesired reactions of cyclopropyl rings. $^{70} 2 \mathrm{~mL}$ of freshly prepared $0.2 \mathrm{M} \mathrm{KOH}$ in methanol was added, samples were then vortexed and incubated for $60 \mathrm{~min}$ at $37^{\circ} \mathrm{C}$ in an oven. When cooled to ambient temperature, $200 \mu \mathrm{L}$ of methanol:glacial acetic acid mixture $(9: 1 \mathrm{v} / \mathrm{v})$ was added. Fatty acid methyl esters (FAME) were extracted with $3 \mathrm{~mL}$ aliquot of hexane by shaking the vial on a vortex mixer for 10 minutes. Phases were separated by centrifugation for $10 \mathrm{~min}$ at $2000 \mathrm{rpm}$ and $4{ }^{\circ} \mathrm{C}$. The upper organic layer was collected with a Pasteur pipette and transferred into $10 \mathrm{~mL}$ vial with PTFE cap. The three last steps were repeated twice with another two $3 \mathrm{~mL}$ aliquots of hexane. Approx. $9 \mathrm{~mL}$ hexane extract containing FAME was obtained, later concentrated under a gentle stream of nitrogen to the volume of approx. 100 $\mu \mathrm{L}$, and 21:0 FAME solution serving as an internal standard was added. The extract was transferred with a Pasteur pipette into a glass insert placed in a GC vial. $10 \mathrm{~mL}$ vial was washed twice with $75 \mu \mathrm{L}$ of hexane and transferred into the glass insert. Finally, the extract was concentrated to the volume of approx. $50 \mu \mathrm{L}$ under a gentle stream of nitrogen. The vial was closed with PTFE lined cap and stored at $-20^{\circ} \mathrm{C}$ prior to analysis. An internal standard solution was added prior to $\mathrm{GC}$ analysis.

\section{GC-C-IRMS analysis}

The carbon isotope ratios of FAMEs obtained both from liquid and soil microcosms were determined by GC-C-IRMS analysis. The same GC-C-IRMS system as for carbon isotope analysis of $\mathrm{CO}_{2}$ was employed but an SGE BPX-5 column $(30 \mathrm{~m} \times 0.32 \mathrm{~m} \times 0.25 \mu \mathrm{m})$ was used for FAME separation. Five microliters of the extract were injected into the injector of the GC. The injector port was maintained at $250{ }^{\circ} \mathrm{C}$ and operated in splitless mode with constant flow of helium as a carrier gas at $2 \mathrm{~mL} / \mathrm{min}$. The temperature program was as follows: the initial temperature of the oven was $70{ }^{\circ} \mathrm{C}$ (held for $1 \mathrm{~min}$ ), ramped at $20^{\circ} \mathrm{C} / \mathrm{min}$ to $130{ }^{\circ} \mathrm{C}$ (held for $0 \mathrm{~min}$ ), ramped at 2 ${ }^{\circ} \mathrm{C} / \mathrm{min}$ to $150{ }^{\circ} \mathrm{C}$ (held for $5 \mathrm{~min}$ ), ramped at $2{ }^{\circ} \mathrm{C} / \mathrm{min}$ to $165{ }^{\circ} \mathrm{C}$ (held for $5 \mathrm{~min}$ ), ramped at 2 
${ }^{\circ} \mathrm{C} / \mathrm{min}$ to $230{ }^{\circ} \mathrm{C}$ (held for $0 \mathrm{~min}$ ), ramped at $20^{\circ} \mathrm{C} / \mathrm{min}$ to $300{ }^{\circ} \mathrm{C}$ (held for $10 \mathrm{~min}$ ). A solution of FAME standards was analyzed under the same conditions for identification based on retention times.

\section{Determination of metabolites}

A set of standards was obtained from Sigma-Aldrich and a protocol was proposed for extraction and derivatization of the selected analytes (provided on Fig. 8). In the following sections, experiments conducted on standard solutions of the selected analytes are described briefly. All the analytes were converted into trimetyhlsilyl (TMS) derivatives. One exception was benzaldehyde, which was first converted into oxime via reaction with hydroxylamine. For testing the derivatization reaction and to obtain mass spectrometry (MS) spectra of the derivatives, each analyte was dissolved in dichloromethane and $10 \mu \mathrm{L}$ aliquot of the solution was evaporated to dryness under gentle stream of nitrogen in a glass insert. In the case of benzaldehyde, oxime derivative must have been obtained preparatively via reaction of benzaldehyde with hydroxylamine under alkaline conditions in water - ethanol mixture at $60^{\circ} \mathrm{C}$ for 60 minutes. The product was then extracted with dichloromethane. Next, $50 \mu \mathrm{L}$ of N,O-bis(trimethylsilyl)trifluoroacetamide (BSTFA) was added and samples were incubated at $60^{\circ} \mathrm{C}$ for 60 minutes. Thus prepared samples were analyzed by GCxGC-TOF-MS.

\section{Liquid microcosms}

A previously frozen sample was defrosted and $800 \mu \mathrm{L}$ of the supernatant was transferred to 1.5 $\mathrm{mL} \mathrm{GC} \mathrm{vial.} \mathrm{The} \mathrm{sample} \mathrm{was} \mathrm{alkalized} \mathrm{to} \mathrm{pH} 11$ by addition of $10 \mu \mathrm{L}$ of $5 \mathrm{M} \mathrm{NaOH}$. Next, $20 \mu \mathrm{L}$ of $50 \mathrm{mg} / \mathrm{mL}$ solution of hydroxylamine hydrochloride in water was added, vortexed and incubated at $60{ }^{\circ} \mathrm{C}$ for $1 \mathrm{~h}$. Amines and neutrals were extracted as follows. The sample was extracted with three $500 \mu \mathrm{L}$ aliquots of diethyl ether, then extracted with $500 \mu \mathrm{L}$ aliquot of $n$-pentane. Fractions were collected in a $4 \mathrm{~mL}$ glass vial. Acids and phenols were extracted as follows. The sample was acidified to $\mathrm{pH} 2$ by addition of $12.5 \mu \mathrm{L}$ of conc. $\mathrm{HCl}$. The sample was extracted with three 500 $\mu \mathrm{L}$ aliquots of diethyl ether, then extracted with $500 \mu \mathrm{L}$ aliquot of $n$-pentane. The fractions were combined in the vial with the fractions collected previously, extracts were dried with a small portion of anhydrous $\mathrm{Na}_{2} \mathrm{SO}_{4}$, then concentrated under gentle stream of nitrogen (ambient temperature) to the volume of approx. $200 \mu \mathrm{L}$. The extract was collected with a Pasteur pipette and 
transferred into a $400 \mu \mathrm{L}$ glass insert placed in a $1.5 \mathrm{~mL}$ GC vial. The remaining drying agent was washed with two $100 \mu \mathrm{L}$ aliquots of diethyl ether and the washings were combined with the extract in the insert. Extracts were evaporated to dryness under a gentle stream of nitrogen (ambient temperature). Next, silylation of the oxime, amine, acidic, and phenolic groups was carried out by adding $50 \mu \mathrm{L}$ of BSTFA, shaken and incubated at $60{ }^{\circ} \mathrm{C}$ for $30 \mathrm{~min}$. The samples were directly analyzed by GCxGC-TOF-MS.

\section{Soil microcosms}

$1.5 \mathrm{~mL}$ of extract from a previously prepared sample was transferred to a $1.5 \mathrm{~mL} \mathrm{GC}$ vial. Conversion of the carbonyl compounds into oximes was carried out. The sample was alkalized to $\mathrm{pH} 11$ by addition of $30 \mu \mathrm{L}$ of $1 \mathrm{M} \mathrm{NaOH}$ in ethanol, then $50 \mu \mathrm{L}$ of $50 \mathrm{mg} / \mathrm{mL}$ solution of hydroxylamine hydrochloride in ethanol was added. The sample was vortexed and incubated at 60 ${ }^{\circ} \mathrm{C}$ for $1 \mathrm{~h}$. Extracts were concentrated under a gentle stream of nitrogen (ambient temperature) to the volume of approx. $200 \mu \mathrm{L}$, then collected with a Pasteur pipette and transferred into a $400 \mu \mathrm{L}$ glass insert placed in a $1.5 \mathrm{~mL}$ GC vial. The vial was washed with two $100 \mu \mathrm{L}$ aliquots of diethyl ether, and the washings were combined with the extract in the insert. The extract was evaporated to dryness under a gentle stream of nitrogen (ambient temperature). Silylation of the oximes, amines, acidic and phenolic groups was carried out by addition of $50 \mu \mathrm{L}$ of BSTFA, the samples were shaken and incubated at $60^{\circ} \mathrm{C}$ for $30 \mathrm{~min}$. The samples were then analyzed by GCxGC-TOFMS.

\section{GCxGC-TOF-MS analysis}

The samples were analyzed by comprehensive two dimensional gas chromatography coupled to time of flight mass spectrometry (GCxGC-TOF-MS) using an Agilent 7890 gas chromatograph and LECO Pegasus 4D TOF-MS mass spectrometer. Column setup - 1st dimension SGE BPX5, $30 \mathrm{~m}, 250 \mu \mathrm{m}, 0.25 \mu \mathrm{m}$; 2nd dimension Restek RXI-17, $0.95 \mathrm{~m}$ (10 cm in the modulator, $74 \mathrm{~cm}$ in the secondary oven, $21 \mathrm{~cm}$ in the transfer line), $100 \mu \mathrm{m}, 0.1 \mu \mathrm{m}$, split/splitless injector operating in splitless mode at $250^{\circ} \mathrm{C}, 1 \mu \mathrm{L}$ injected, split vent open after $40 \mathrm{~s}$. Separation conditions - carrier gas (helium) flow constant at $1 \mathrm{~mL} / \mathrm{min}$, main oven program: $60{ }^{\circ} \mathrm{C}$ held for $1 \mathrm{~min}$, than ramped to $280{ }^{\circ} \mathrm{C}$ at $4{ }^{\circ} \mathrm{C} / \mathrm{min}$ and held for $20 \mathrm{~min}$, secondary oven program: $65^{\circ} \mathrm{C}$ held for $4 \mathrm{~min}$, than ramped to $290{ }^{\circ} \mathrm{C}$ at $4{ }^{\circ} \mathrm{C} / \mathrm{min}$, the modulator temperature was set $25^{\circ} \mathrm{C}$ above the temperature of 
the secondary oven, modulation period $3 \mathrm{~s}$. Detection conditions - ion source temperature $250{ }^{\circ} \mathrm{C}$, ion source voltage $70 \mathrm{eV}$, solvent delay $400 \mathrm{~s}$, acquisition range $25-500 \mathrm{~m} / \mathrm{z}$, acquisition rate 150 spectra/s.

\section{Acknowledgements}

We thank Hans-Hermann Richnow for his support during the planning of the experiments. This study was conducted in the frame of OPUS 15 funded by the National Science Centre in Poland, conferred on the basis of decision DEC-2018/29/B/NZ9/01136. Grant title "Bioaugmentation with herbicide degrading bacteria as a potential factor in spreading resistance to herbicides among plants".

\section{Conflict of interest statement}

Robin D. Rogers and Juliusz Pernak are named inventors on related patents and applications which have been licensed to an independent third party.

\section{Associated content}

Electronical Supplement Information (ESI): syntheses schemes, NMR spectra, figure demonstrating the concentration of cation in liquid microcosms, chromatograms presenting FAMEs from liquid and soil microcosms, identified FAMEs, chromatogram of TMS derivatives present in analytes, identified TMS derivatives, experimental set-ups, soil characteristics, recoveries of ions from liquid and soil microcosms and calibration curves.

\section{References}

(1) Wasserscheid, P.; Keim, W. Ionic Liquids - New "Solutions" for Transition Metal Catalysis. Angew. Chem. Int. Ed. 2010, 39, 3772-3789. https://doi.org/10.1002/15213773(20001103)39:21<3772::aid-anie3772>3.0.co;2-5.

(2) Plechkova, N. V.; Seddon, K. R. Applications of Ionic Liquids in the Chemical Industry. Chem. Soc. Rev. 2008, 37 (1), 123-150. https://doi.org/10.1039/b006677j.

(3) Smiglak, M.; Pringle, J. M.; Lu, X.; Han, L.; Zhang, S.; Gao, H.; MacFarlane, D. R.; Rogers, R. D. Ionic Liquids for Energy, Materials, and Medicine. Chem. Commun. 2014, 50 (66), 9228-9250. https://doi.org/10.1039/c4cc02021a. 
(4) Pernak, J.; Syguda, A.; Janiszewska, D.; Materna, K.; Praczyk, T. Ionic Liquids with Herbicidal Anions. Tetrahedron 2011, $67 \quad$ (26), 4838-4844. https://doi.org/10.1016/j.tet.2011.05.016.

(5) Gavrilescu, M. Fate of Pesticides in the Environment and Its Bioremediation. Eng. Life Sci. 2005, 5 (6), 497-526. https://doi.org/10.1002/elsc.200520098.

(6) Kudsk, P.; Streibig, J. C. Herbicides - A Two-Edged Sword. Weed Res. 2003, 43 (2), 90102. https://doi.org/10.1046/j.1365-3180.2003.00328.x.

(7) Oerke, E.-C. Crop Losses to Pests. J. Agric. Sci. 2006, 144 (1), 31-43. https://doi.org/10.1017/S0021859605005708.

(8) Defarge, N.; Spiroux de Vendômois, J.; Séralini, G. E. Toxicity of Formulants and Heavy Metals in Glyphosate-Based Herbicides and Other Pesticides. Toxicol. Reports 2018, 5 (October 2017), 156-163. https://doi.org/10.1016/j.toxrep.2017.12.025.

(9) Hough, W. L.; Smiglak, M.; Rodríguez, H.; Swatloski, R. P.; Spear, S. K.; Daly, D. T.; Pernak, J.; Grisel, J. E.; Carliss, R. D.; Soutullo, M. D.; et al. The Third Evolution of Ionic Liquids: Active Pharmaceutical Ingredients. New J. Chem. 2007, 31 (8), 1429. https://doi.org/10.1039/b706677p.

(10) Pernak, J.; Niemczak, M.; Chrzanowski, Ł.; Ławniczak, Ł.; Fochtman, P.; Marcinkowska, K.; Praczyk, T. Betaine and Carnitine Derivatives as Herbicidal Ionic Liquids. Chem. - A Eur. J. 2016, 22 (34), 12012-12021. https://doi.org/10.1002/chem.201601952.

(11) Choudhary, H.; Pernak, J.; Shamshina, J. L.; Niemczak, M.; Giszter, R.; Chrzanowski, Ł.; Praczyk, T.; Marcinkowska, K.; Cojocaru, O. A.; Rogers, R. D. Two Herbicides in a Single Compound: Double Salt Herbicidal Ionic Liquids Exemplified with Glyphosate, Dicamba, and MCPA. ACS Sustain. Chem. Eng. 2017, 5 (7), 6261-6273. https://doi.org/10.1021/acssuschemeng.7b01224.

(12) Tang, G.; Liu, Y.; Ding, G.; Zhang, W.; Liang, Y.; Fan, C.; Dong, H.; Yang, J.; Kong, D.; Cao, Y. Ionic Liquids Based on Bromoxynil for Reducing Adverse Impacts on the Environment and Human Health. New J. Chem. 2017, 41 (16), 8650-8655. https://doi.org/10.1039/c7nj01694h. 
(13) Niemczak, M.; Chrzanowski, Ł.; Praczyk, T.; Pernak, J. Biodegradable Herbicidal Ionic Liquids Based on Synthetic Auxins and Analogues of Betaine. New J. Chem. 2017, 41 (16), 8066-8077. https://doi.org/10.1039/c7nj01474k.

(14) Niemczak, M.; Rzemieniecki, T.; Biedziak, A.; Marcinkowska, K.; Pernak, J. Synthesis and Structure-Property Relationships in Herbicidal Ionic Liquids and Their Double Salts. Chempluschem 2018, 83 (6), 529-541. https://doi.org/10.1002/cplu.201800251.

(15) Pernak, J.; Czerniak, K.; Niemczak, M.; Lawniczak, Ł.; Kaczmarek, D. K.; Borkowski, A.; Praczyk, T. Bioherbicidal Ionic Liquids. ACS Sustain. Chem. Eng. 2018, 6 (2), 2741-2750. https://doi.org/10.1021/acssuschemeng.7b04382.

(16) Pernak, J.; Czerniak, K.; Niemczak, M.; Chrzanowski, Ł.; Ławniczak, Ł.; Fochtman, P.; Marcinkowska, K.; Praczyk, T. Herbicidal Ionic Liquids Based on Esterquats. New J. Chem. 2015, 39 (7), 5715-5724. https://doi.org/10.1039/c5nj00609k.

(17) Borkowski, A.; Ławniczak, Ł.; Cłapa, T.; Narozna, D.; Selwet, M.; Peziak, D.; Markiewicz, B.; Chrzanowski, Ł. Different Antibacterial Activity of Novel Theophylline-Based Ionic Liquids - Growth Kinetic and Cytotoxicity Studies. Ecotoxicol. Environ. Saf. 2016, 130, 54 64. https://doi.org/10.1016/j.ecoenv.2016.04.004.

(18) Turguła, A.; Materna, K.; Gwiazdowska, D.; Walkiewicz, F.; Marcinkowska, K.; Pernak, J. Difunctional Ammonium Ionic Liquids with Bicyclic Cations. New J. Chem. 2019, 43 (11), 4477-4488. https://doi.org/10.1039/C8NJ06054A.

(19) Piotrowska, A.; Syguda, A.; Chrzanowski, Ł.; Heipieper, H. J. Toxicity of Synthetic Herbicides Containing 2,4-D and MCPA Moieties towards Pseudomonas Putida Mt-2 and Its Response at the Level of Membrane Fatty Acid Composition. Chemosphere 2016, 144, 107-112. https://doi.org/10.1016/j.chemosphere.2015.08.067.

(20) Piotrowska, A.; Syguda, A.; Wyrwas, B.; Chrzanowski, Ł.; Heipieper, H. J. Toxicity Evaluation of Selected Ammonium-Based Ionic Liquid Forms with MCPP and Dicamba Moieties on Pseudomonas Putida. Chemosphere 2017, 167, 114-119. https://doi.org/10.1016/j.chemosphere.2016.09.140.

(21) Neilson, A. H.; Allard, A.-S. Environmental Degradation and Transformation of Organic 
Chemicals; CRC Press/Taylor \& Francis: London, New York, 2008.

(22) Sydow, M.; Szczepaniak, Z.; Framski, G.; Staninska, J.; Owsianiak, M.; Szulc, A.; Piotrowska-Cyplik, A.; Zgoła-Grześkowiak, A.; Wyrwas, B.; Chrzanowski, L. Persistence of Selected Ammonium- and Phosphonium-Based Ionic Liquids in Urban Park Soil Microcosms. Int. Biodeterior. Biodegrad. 2015, 103, 91-96. https://doi.org/10.1016/j.ibiod.2015.04.019.

(23) Jastorff, B.; Störmann, R.; Ranke, J.; Mölter, K.; Stock, F.; Oberheitmann, B.; Hoffmann, W.; Hoffmann, J.; Nüchter, M.; Ondruschka, B.; et al. How Hazardous Are Ionic Liquids? Structure-Activity Relationships and Biological Testing as Important Elements for Sustainability Evaluation. Green Chem. 2003, 5 (2), 136-142. https://doi.org/10.1039/b211971d.

(24) OECD Guideline for Testing of Chemicals, Proposal for Revised Introduction to the OECD Guidelines for Testing of Chemicals, Section 3. 2005, 1-13.

(25) Pęziak-Kowalska, D.; Syguda, A.; Ławniczak, Ł.; Borkowski, A.; Fourcade, F.; Heipieper, H. J.; Lota, G.; Chrzanowski, Ł. Hybrid Electrochemical and Biological Treatment of Herbicidal Ionic Liquids Comprising the MCPA Anion. Ecotoxicol. Environ. Saf. 2019, 181 (March), 172-179. https://doi.org/10.1016/j.ecoenv.2019.05.084.

(26) Sydow, M.; Owsianiak, M.; Framski, G.; Woźniak-Karczewska, M.; Piotrowska-Cyplik, A.; Ławniczak, Ł.; Szulc, A.; Zgoła-Grześkowiak, A.; Heipieper, H. J.; Chrzanowski, Ł. Biodiversity of Soil Bacteria Exposed to Sub-Lethal Concentrations of Phosphonium-Based Ionic Liquids: Effects of Toxicity and Biodegradation. Ecotoxicol. Environ. Saf. 2018, 147 (February 2017), 157-164. https://doi.org/10.1016/j.ecoenv.2017.08.026.

(27) Fischer, A.; Manefield, M.; Bombach, P. Application of Stable Isotope Tools for Evaluating Natural and Stimulated Biodegradation of Organic Pollutants in Field Studies. Curr. Opin. Biotechnol. 2016, 41 (1), 99-107. https://doi.org/10.1016/j.copbio.2016.04.026.

(28) Kümmel, S.; Herbst, F. A.; Bahr, A.; Duarte, M.; Pieper, D. H.; Jehmlich, N.; Seifert, J.; Von Bergen, M.; Bombach, P.; Richnow, H. H.; et al. Anaerobic Naphthalene Degradation by Sulfatereducing Desulfobacteraceae from Various Anoxic Aquifers. FEMS Microbiol. Ecol. 2015, 91 (3), 1-13. https://doi.org/10.1093/femsec/fiv006. 
(29) Bahr, A.; Fischer, A.; Vogt, C.; Bombach, P. Evidence of Polycyclic Aromatic Hydrocarbon Biodegradation in a Contaminated Aquifer by Combined Application of in Situ and Laboratory Microcosms Using 13C-Labelled Target Compounds. Water Res. 2015, 69, 100109. https://doi.org/10.1016/j.watres.2014.10.045.

(30) Morasch, B.; Hunkeler, D.; Zopfi, J.; Temime, B.; Höhener, P. Intrinsic Biodegradation Potential of Aromatic Hydrocarbons in an Alluvial Aquifer - Potentials and Limits of Signature Metabolite Analysis and Two Stable Isotope-Based Techniques. Water Res. 2011, 45 (15), 4459-4469. https://doi.org/10.1016/j.watres.2011.05.040.

(31) Schmidt, M.; Wolfram, D.; Birkigt, J.; Ahlheim, J.; Paschke, H.; Richnow, H. H.; Nijenhuis, I. Iron Oxides Stimulate Microbial Monochlorobenzene in Situ Transformation in Constructed Wetlands and Laboratory Systems. Sci. Total Environ. 2014, 472, 185-193. https://doi.org/10.1016/j.scitotenv.2013.10.116.

(32) Tomco, P. L.; Holmes, W. E.; Tjeerdema, R. S. Biodegradation of Clomazone in a California Rice Field Soil: Carbon Allocation and Community Effects. J. Agric. Food Chem. 2013, 61 (11), 2618-2624. https://doi.org/10.1021/jf304692c.

(33) Atwood, D.; Paisley-Jones, C. Pesticides Industry Sales and Usage, 2008 - 2012 Market Estimates. United States Environ. Prot. Agency 2017, 1-24.

(34) Syguda, A.; Marcinkowska, K.; Materna, K. Pyrrolidinium Herbicidal Ionic Liquids. RSC Adv. 2016, 6 (68), 63136-63142. https://doi.org/10.1039/c6ra12157h.

(35) Giszter, R.; Fryder, M.; Marcinkowska, K.; Sznajdrowska, A. Synthesis, Surface Properties and Biological Activity of Long Chain Ammonium Herbicidal Ionic Liquids. J. Braz. Chem. Soc. 2016, 27, 1774-1781.

(36) Martínez-Carballo, E.; González-Barreiro, C.; Sitka, A.; Kreuzinger, N.; Scharf, S.; Gans, O. Determination of Selected Quaternary Ammonium Compounds by Liquid Chromatography with Mass Spectrometry. Part II. Application to Sediment and Sludge Samples in Austria. Environ. Pollut. 2007, 146 (2), 543-547. https://doi.org/10.1016/j.envpol.2006.07.016.

(37) https://sitem.herts.ac.uk/aeru/iupac/atoz.htm, accessed August 1, 2019. 
(38) Zanini, G. P.; Ovesen, R. G.; Hansen, H. C. B.; Strobel, B. W. Adsorption of the Disinfectant Benzalkonium Chloride on Montmorillonite. Synergistic Effect in Mixture of Molecules with Different Chain Lengths. J. Environ. Manage. 2013, 128, 100-105. https://doi.org/10.1016/j.jenvman.2013.04.056.

(39) Datta, S.; Baudouin, C.; Brignole-Baudouin, F.; Denoyer, A.; Cortopassi, G. A. The Eye Drop Preservative Benzalkonium Chloride Potently Induces Mitochondrial Dysfunction and Preferentially Affects LHON Mutant Cells. Investig. Ophthalmol. Vis. Sci. 2017, 58 (4), 2406-2412. https://doi.org/10.1167/iovs.16-20903.

(40) Wang, L.; Zhang, Y.; Ding, L.; Liu, J.; Zhao, B.; Deng, Q.; Yan, T. Synthesis and Physiochemical Properties of Novel Gemini Surfactants with Phenyl-1,4Bis(Carbamoylmethyl) $\quad$ Spacer. $\quad R S C \quad A d v . \quad 2015, \quad 5 \quad$ (91), $74764-74773$. https://doi.org/10.1039/c5ra13616d.

(41) Khan, A. H.; Topp, E.; Scott, A.; Sumarah, M.; Macfie, S. M.; Ray, M. B. Biodegradation of Benzalkonium Chlorides Singly and in Mixtures by a Pseudomonas Sp. Isolated from Returned Activated Sludge. J. Hazard. Mater. 2015, 299, 595-602. https://doi.org/10.1016/j.jhazmat.2015.07.073.

(42) Paszko, T.; Muszyński, P.; Materska, M.; Bojanowska, M.; Kostecka, M.; Jackowska, I. Adsorption and Degradation of Phenoxyalkanoic Acid Herbicides in Soils: A Review. Environ. Toxicol. Chem. 2016, 35 (2), 271-286. https://doi.org/10.1002/etc.3212.

(43) Audus, L. J. The Biological Detoxication of Hormone Herbicides in Soil. Plant Soil 1951, $3(2), 170-192$.

(44) Pernak, J.; Praczyk, T.; Janiszewska, D.; Urbanek, M.; Gnatek, R.; Lorys, B.; Kloczko, J.; Pec, J. New Ionic Pairs with (4-Chloro-2-Methylphenoxy)Acetate and Their Syntheses. Patent Application WO 2008/140338, 2008.

(45) Syguda, A.; Jakubiak, E.; Materna, K. Ionic Liquids with (4-Chloro-2Methylphenoxy)Acetate Anion. Przem. Chem. 2013, 92 (9), 1677-1679.

(46) Czarny, J.; Piotrowska-Cyplik, A.; Lewicki, A.; Zgoła-Grześkowiak, A.; Wolko, Ł.; Galant, N.; Syguda, A.; Cyplik, P. The Toxic Effect of Herbicidal Ionic Liquids on Biogas- 
Producing Microbial Community. Int. J. Environ. Res. Public Health 2019, 16 (6), 916. https://doi.org/10.3390/ijerph16060916.

(47) Moret, S.; Sánchez, J. M.; Salvadó, V.; Hidalgo, M. The Evaluation of Different Sorbents for the Preconcentration of Phenoxyacetic Acid Herbicides and Their Metabolites from $\begin{array}{lllllll}\text { Soils. } & J & \text { Chromatogr. } & A & \text { 2005, } & 1099 & (1-2),\end{array}$ https://doi.org/10.1016/j.chroma.2005.08.078.

(48) Pernak, J.; Syguda, A.; Materna, K.; Janus, E.; Kardasz, P.; Praczyk, T. 2,4-D Based Herbicidal Ionic Liquids. Tetrahedron 2012, 68 (22), 4267-4273. https://doi.org/10.1016/j.tet.2012.03.065.

(49) Gerba, C. P. Quaternary Ammonium Biocides: Efficacy in Application. Appl. Environ. Microbiol. 2015, 81 (2), 464-469. https://doi.org/10.1128/AEM.02633-14.

(50) Tezel, U.; Tandukar, M.; Martinez, R. J.; Sobecky, P. A.; Pavlostathis, S. G. Aerobic Biotransformation of N-Tetradecylbenzyldimethylammonium Chloride by an Enriched Pseudomonas Spp. Community. Environ. Sci. Technol. 2012, 46 (16), 8714-8722. https://doi.org/10.1021/es300518c.

(51) Cierniak, D.; Woźniak-Karczewska, M.; Parus, A.; Wyrwas, B.; Loibner, A. P.; Heipieper, H. J.; Ławniczak, Ł.; Chrzanowski, Ł. How to Accurately Assess Surfactant Biodegradation - Impact of Sorption on the Validity of Results. Appl. Microbiol. Biotechnol. 2020. https://doi.org/10.1007/s00253-019-10202-9.

(52) Bastida, F.; Jechalke, S.; Bombach, P.; Franchini, A. G.; Seifert, J.; von Bergen, M.; Vogt, C.; Richnow, H. H. Assimilation of Benzene Carbon through Multiple Trophic Levels Traced by Different Stable Isotope Probing Methodologies. FEMS Microbiol. Ecol. 2011, 77 (2), 357-369. https://doi.org/10.1111/j.1574-6941.2011.01118.x.

(53) Bombach, P.; Chatzinotas, A.; Neu, T. R.; Kästner, M.; Lueders, T.; Vogt, C. Enrichment and Characterization of a Sulfate-Reducing Toluene-Degrading Microbial Consortium by Combining in Situ Microcosms and Stable Isotope Probing Techniques. FEMS Microbiol. Ecol. 2010, 71 (2), 237-246. https://doi.org/10.1111/j.1574-6941.2009.00809.x.

(54) Dungait, J. A. J.; Kemmitt, S. J.; Michallon, L.; Guo, S.; Wen, Q.; Brookes, P. C.; Evershed, 
R. P. Variable Responses of the Soil Microbial Biomass to Trace Concentrations of 13CLabelled Glucose, Using 13C-PLFA Analysis. Eur. J. Soil Sci. 2011, 62 (1), 117-126. https://doi.org/10.1111/j.1365-2389.2010.01321.x.

(55) Patrauchan, M. A.; Oriel, P. J. Degradation of Benzyldimethylalkylammonium Chloride by Aeromonas Hydrophila Sp. K. J. Appl. Microbiol. 2003, 94 (2), 266-272. https://doi.org/10.1046/j.1365-2672.2003.01829.x.

(56) Liu, Y. J.; Liu, S. J.; Drake, H. L.; Horn, M. A. Alphaproteobacteria Dominate Active 2Methyl-4-Chlorophenoxyacetic Acid Herbicide Degraders in Agricultural Soil and Drilosphere. Environ. Microbiol. 2011, 13 (4), 991-1009. https://doi.org/10.1111/j.14622920.2010.02405.x.

(57) Khan, A. H.; Macfie, S. M.; Ray, M. B. Sorption and Leaching of Benzalkonium Chlorides in Agricultural Soils. J. Environ. Manage. 2017, 196, 26-35. https://doi.org/10.1016/j.jenvman.2017.02.065.

(58) Morais, S. A.; Delerue-Matos, C.; Gabarrell, X.; Blánquez, P. Multimedia Fate Modeling and Comparative Impact on Freshwater Ecosystems of Pharmaceuticals from BiosolidsAmended Soils. Chemosphere 2013, $93 \quad$ (2), 252-262. https://doi.org/10.1016/j.chemosphere.2013.04.074.

(59) Fantke, P.; Bijster, M.; Guignard, C.; Hauschild, M.; Huijbregts, M.; Jolliet, O.; Kounina, A.; Magaud, V.; Margni, M.; McKone, T.; et al. USEtox ${ }^{\circledR} 2.0$, Documentation Version 1.1. 2018, 1-208.

(60) Ławniczak, Ł.; Materna, K.; Framski, G.; Szulc, A.; Syguda, A. Comparative Study on the Biodegradability of Morpholinium Herbicidal Ionic Liquids. Biodegradation 2015, 26 (4), 327-340. https://doi.org/10.1007/s10532-015-9737-2.

(61) Whiteley, A. S.; Manefield, M.; Lueders, T. Unlocking the "microbial Black Box" Using RNA-Based Stable Isotope Probing Technologies. Curr. Opin. Biotechnol. 2006, 17 (1), 6771. https://doi.org/10.1016/j.copbio.2005.11.002.

(62) Uhlík, O.; Jecná, K.; Leigh, M. B.; Macková, M.; Macek, T. DNA-Based Stable Isotope Probing: A Link between Community Structure and Function. Sci. Total Environ. 2009, 407 
(12), 3611-3619. https://doi.org/10.1016/j.scitotenv.2008.05.012.

(63) Jehmlich, N.; Vogt, C.; Lünsmann, V.; Richnow, H. H.; von Bergen, M. Protein-SIP in Environmental Studies. Curr. Opin. Biotechnol. 2016, 41, 26-33. https://doi.org/10.1016/j.copbio.2016.04.010.

(64) Coplen, T. B. Guidelines and Recommended Terms for Expression of Stable-Isotope-Ratio and Gas-Ratio Measurement Results. Rapid Commun. Mass Spectrom. 2011, 25 (17), 25382560. https://doi.org/10.1002/rcm.5129.

(65) Zhang, Q. L. .; Chang, T. L. .; Li, W. J. A Calibrated Measurement of the Atomic-Weight of Carbon. Chinese Sci. Bull. 1990, 1990, 35 (4), 290-296. https://doi.org/10.1360/sb199035-4-290.

(66) Slater, C.; Preston, T.; Weaver, L. T. Stable Isotopes and the International System of Units. Rapid Commun. Mass Spectrom. 2001, 15 (15), 1270-1273. https://doi.org/10.1002/rcm.328.

(67) Sander, R. Compilation of Henry's Law Constants (Version 4.0) for Water as Solvent. Atmos. Chem. Phys. 2015, 15 (8), 4399-4981. https://doi.org/10.5194/acp-15-4399-2015.

(68) Bligh, E. G.; Dyer, W. J. A Rapid Method of Total Lipid Extraction and Purification. Can. J. Biochem. Physiol. 1959, 37, 911-917. https://doi.org/dx.doi.org/10.1139/cjz-2013-0052.

(69) Bossio, D. A.; Scow, K. M. Impacts of Carbon and Flooding on Soil Microbial Communities: Phospholipid Fatty Acid Profiles and Substrate Utilization Patterns. Microb. Ecol. 1998, 35, 265-278. https://doi.org/10.1007/s002489900082.

(70) Guckert, J. B.; Antworth, C. P.; Nichols, P. D.; White, D. C. Phospholipid, Ester-Linked Fatty Acid Profiles as Reproducible Assays for Changes in Prokaryotic Community Structure of Estuarine Sediments. FEMS Microbiol. Ecol. 1985, 31 (3), 147-158. 


\section{For Table of Contents Only}

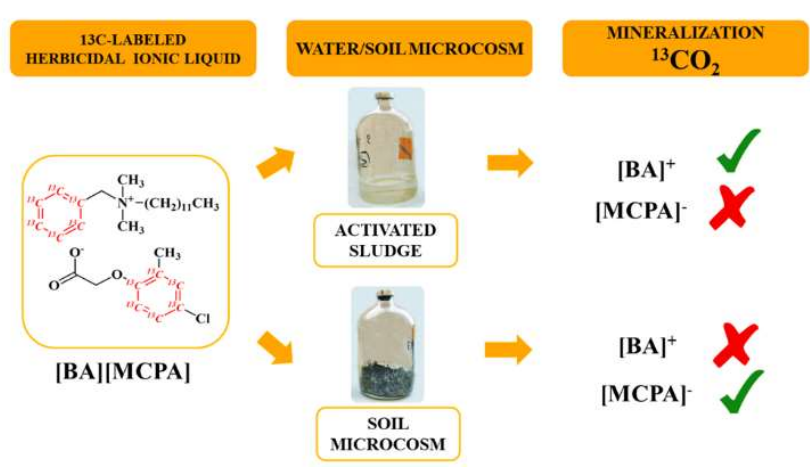

